\title{
Türkistan’ın İsgali ve Sovyetleştirilmesi Sürecinde Ermeniler ve Bölgede Yaptıkları Katliamlar
}

\author{
Seyfi Yıldırım* - Mirzahan Egamberdiyev**
}

\begin{abstract}
$\ddot{\mathbf{O} z}$
Çarlık Rusyasının güçlenmesi ile birlikte 19. asırda bilhassa Kafkasya ve Türkistan coğrafyasında daha önce başlamış olan yayılma faaliyetleri resmen işgale dönüştü. Çarlık bir taraftan Anadolu'da başlayan Ermeni ayaklanmalarını desteklerken diğer taraftan işgal edilen Türkistan topraklarına Ermeniler iskân etmekteydi. Ermeniler Rusların bu topraklardaki işgallerinde faydalı bir müttefik idi. Ermeni-Rus işbirliğinden Ermenilerin beklentisi ise bağımsız bir Ermenistan kurabilmekti. Aynı zamanda bu gücün desteğini almak onlar için maddi-manevi güç elde etmek anlamına gelmekteydi. Ermeniler Türkistan'da Rus desteğiyle büyük bir güç elde ettiler. Bu coğrafyada para kazandıracak işlerin çoğunluğunu ele geçirdikleri gibi daima yerli ahalinin elinden alınan verimli topraklarda iskân edildiler. Ermenilerin bu şekilde iskân, istihdam ve asker olarak kullanılmaları Çarlık yönetimin sona ermesi ile kurulan Bolşevik idaresinde de değişmeyen bir yöntem oldu. Çoğunluğu yerli Taşnak olan bu Ermeniler Bolşeviklerle birlikte Türkistan coğrafyasında ortaya çıkan Milli Mücadele’nin kanlı bir şekilde bastırılmasında büyük bir rol oynadılar.
\end{abstract}

Anahtar Kelimeler: Ermeniler, Kızıl Kıtlık, Bolşevik İhtilali, Basmacı Hareketi, Türkistan Milli Mücadelesi

* Doç. Dr., Hacettepe Üniversitesi, Atatürk İlkeleri ve İnkılap Tarihi Enstitüsü, Ankara/ TÜRKIYE, ahiseyfi@hotmail.com ORCID: 0000-0002-3318-6089

** Assoc. Prof. Dr., Al-Farabi Kazakh National University, Faculty of Oriental Studies, Department of TURKSOY, Almaty/KAZAKHSTAN, mirzahan.egamberdiyev@gmail.com

ORCID: 0000-0002-1022-0483

DOI:

Makale Gönderim Tarihi: 14.04.2020 - Makale Kabul Tarihi: 08.02.2021

Belleten, Nisan 2021, Cilt: 85/Sayı: 302; 227-277 


\title{
Armenians and the Massacres They Carried Out during the Occupation and Sovietization of Turkistan
}

\begin{abstract}
With the strengthening of the Tsarist Russia, the expansion activities that had started before, especially in the Caucasus and Turkistan geography in the $19^{\text {th }}$ century, officially turned into occupation. Tsarist Russia supported the Armenian revolts that started in Anatolia and settled the Armenians in the occupied Turkistan lands. The Armenians were a useful ally in the Russian occupation of these lands. The expectation of Armenians from Armenian-Russian cooperation was to establish an independent Armenia. At the same time, getting the support of Russia meant obtaining material and spiritual power for Armenians. Armenians gained a great power in Turkistan with Russian support. In this geography, they occupied most of the jobs that would make money, and they were always settled in the fertile lands that were taken from the local people. The settlement, employment and military use of Armenians in this way became an unchanged method in the Bolshevik administration established after the end of the Tsarist rule. These Armenians, most of whom were indigenous Dashnaks, played a major role in the bloody suppression of the National Struggle that emerged in the Turkistan geography together with the Bolsheviks.
\end{abstract}

Keywords: Armenians, Red Famine, Bolshevik Revolution, Basmacı Movement, Turkistan National Struggle

\section{Giriş}

İki tarafin beklentileri birbirinden elbette farklı olmakla birlikte Ermeni-Rus işbirliğinin tarihi oldukça eskilere gider. Hassaten I. Petro döneminden itibaren, Rus-Ermeni işbirliği, Rusya'nın siyasi ve ekonomik çıkarlarına hizmet edecek önemli bir araç olarak görülmekteydi. Ermenilerin Hristiyan olmaları ve Rusya için bir tehlike oluşturamayacak, kontrol edilebilir bir unsur olması Çarlık yönetimi açısından Ermenileri değerli bir müttefik yapmaktaydı. Rusya açısından yayılma ve genişleme teşebbüsünde ortaya çıkması kaçınılmaz olan çatışma veya gerginliklerde Ermeniler etno-sosyal bir taban oluşturmak için uygun görünüyordu. Ermeniler ise bağımsız bir devlet kurmanın en kestirme yolunun ancak güçlü Rus Çarlığı himayesinden geçtiğini ve bu suretle gerçekleşebileceğini düşünmekte olduklarından, bu işbirliğine hevesle razı oldular. Ermenilerin beklentilerini 
kolayca gören Çarlık yönetimi bundan faydalanarak onları daima kendi işgal ve genişleme siyasetinde bir "meşruiyyet aracı" olarak kullanma stratejisini geliştirdi 1. Bu çerçevede, Rus Çarlığı’nın İran, Kafkasya ve Türkistan işgalinin genişlemesinde ve yerleşmesinde Ermeniler önemli bir rol üstlenmişlerdi. Çarlı yönetimi bilhassa 19. asırda Kafkaslar ve Türkistan eksenindeki yayllma siyasetinde Ermenilerle birlikte çalışmış ve onlardan bu yönde ustaca yararlanmıştır. Nitekim 1826-1828 yılları arasında Rusya ve İran arasında geçen çatışmalarda daha sonra Patriklik makamına kadar yükselen Narses'in de aralarında bulunduğu Ermeni birlikleri Rus ordusunun emrinde savaştı. Yapılan savaşı İran kaybetti ve taraflar arasında 28 Şubat 1828'de Türkmençay Antlaşması imzalandı. Ermeniler, savaşta yaptıkları bu katkıyı ısrarla öne sürerek Rusya'dan bir Ermeni vilayeti kurulmasını talep ettiler. Sonuçta Çar Nikolay'nn 21 Mart 1828 tarihli emri ile imparatorluğun bu antlaşma ile elde ettiği yeni topraklar "Ermeni Eyaleti" olarak kabul edildi. Çar, unvanları arasına aynı zamanda "Ermenistan Kralı" sıfatını da ekledi².

Bir diğer işbirliği Osmanlı Devleti’ne karşı gerçekleşti. Rusya 1828 yılında Yunan isyanı vesilesiyle Osmanlı Devleti'ne savaş açtı ve Rus ordusu Anadolu'ya girdi. Doğu Anadolu'da yaşayan ve Rus tarafinı tercih eden Ermenilerin yardımıyla Ruslar Doğu Anadolu'ya girip Kars, Ahıska, Beyazıt ve Erzurum kalelerini kolayca ele geçirdiler. Edirne Antlaşması (1829) ile bu topraklar tekrar iade edilmekle birlikte müteakip yıllarda Kafkasya adım adım Rus işgali altına girdi ${ }^{3}$. Bu işgalle birlikte bölgeye İran ve Doğu Anadolu'dan çok sayıda Ermeni göç ettirilerek burada iktisadi, siyasi ve askeri olarak egemenlik kurmayı amaçlamaktaydı. Bu suretle Osmanlı Devleti’ne ve İran’a karşı da bir tampon bölge elde edilecek ${ }^{4}$ ve "Hristiyan dayamş̧ması" görüntüsü altında Ermeni nüfusun çeşitli mahallere göç ettirilmesi ile sağlanacak olan etno-sosyal taban orta ve uzun vadede Rus ilerlemesi için sağlam bir zemin oluşturacaktı ${ }^{5}$.

1 Ziyad Emrahov, "Rusya Arşiv Belgelerinde Kafkasya'nın Ermeni Din Adamlarının Osmanlı İmparatorluğu'nda Çıkarılmış İsyanlara (1890-1896 Yılları) Verdiği Destek”, Ermeni Araştırmalar, 2014, S. 49, s. 115-124, s. 116.

2 Halil Özşavlı, "Başlangıçtan I. Dünya Savaşına Kadar Rus-Ermeni İişkileri", The Journal of Academic Social Science Studies International Fournal of Social Science, Vol. 5/2, April 2012, s. 243-268, s. 255.

3 Bürkan Serbest-N. Savaş Demirci, "Kars ve Çevresinde Rus Yönetimi (Karskaya Oblast 1878-1917)" s. 2715-2734,, 38. ICANAS Uluslararası Asya ve Kuzey Afrika Çalısmalan Kongresi, Ankara 2007, s. 2715-2734

4 Özşavlı, agm., s. 257.

5 Emrahov, agm., s. 117. 
Kısmen temas edilen bu işbirliğinin bütün 19. asır boyunca sürdürüldüğünü ve hatta 20. asırda da aynı şekilde devam ettiğini söylemekte beis yoktur. Nitekim 1877-1878'de 93 Harbi olarak bilinen Osmanl-Rus Savaşı'nda Kafkasya Ermenileri ile birlikte Osmanlı Ermenilerinden bir kısmının da Ruslarla işbirliği yaptığı, Rus ordusunda savaştıkları görülmektedir. Bu savaş Ermeniler için yeni bir firsat olmuş, Kafkas Ermenilerinden Loris-Melikov, Der-Gukasov ve Korgeneral Lazarev komutasındaki Rus kuvvetleri Doğu Anadolu'yu işgal edince yerli Ermenilerden bir kısmı onlarla işbirliği yaparak Rus işgal kuvvetlerinin hizmetine girmişlerdi. Savaş sonrasında başlayan Rus-Osmanlı barış görüşmelerinde Ermeni heyeti Osmanlı topraklarında bağımsız bir Ermenistan talebinde bulundular ancak kendilerine yine olumsuz cevap verildi ${ }^{6}$.

93 Harbi sonunda Osmanlı ve Rusya arasında mütareke görüşmeleri başlayınca Patrik Nerses Varjabedyan ve piskoposlardan oluşan Ermeni heyeti Edirne'de Grandük Nikola ve Kont İgnatiyev'le görüşerek anlaşmaya kendileri ile ilgili bir madde konulmasını talep ettiler. Daha sonra 13 Şubat 1878 tarihli bir dilekçe ile Rus Çarı II. Aleksandr ile Başbakan Gorçakof'a müracaat ettiler. Heyetin talebi; Doğu Anadolu'da Ermenilerin yaşadığı vilayetlerin Rusya tarafindan ilhak edilmesi, bu mümkün olmadığı takdirde Bulgaristan'a bahşedilen imtiyazların Ermenilere'de verilmesi, bu da olmadığı takdirde Ermenilerin yaşadığı vilayetlerde kapsamlı ıslahat yapılması ve askeri birlikler teşkil edilmesiydi ${ }^{7}$. Rus Çarlığı Ermenileri kendi işgal ve genişleme politikaları için kullanıyor, Ermeniler ise bağımsız bir Ermenistan’ın kurulması için buna razı görünüyorlardı. Ancak Rusya kendi hâkimiyetinin zarar göreceği, bağımsız bir Ermenistan'ın diğer milletlere de örnek teşkil edeceği düşüncesiyle bu talepleri kabule yanaşmadı. Esasen, Ermeniler tarafindan Anadolu topraklarından talep edilen yerlerde Ermenilerin hiçbir zaman yeterli nüfusa sahip olmadıkları Ruslar tarafindan iyi bilinmekteydi. Bu sebeple heyetin ilk iki talebi ile ortaya koydukları beklentileri Gerek Ayastefenos gerekse Berlin Anlaşmaları'nda boşa çıkmış ve her iki anlaşmada Ermeniler ancak kendileri ile ilgili olarak sslahat yapılması hususundaki zayıf hüküm içeren bir madde ile yetinmek zorunda kalmışlardı.

6 Özşavlı, agm., s. 259.

7 Yüksel Çelik, "Ayestefanos ve Berlin Antlaşmalarıyla Ermeni Meselesi'nin Uluslararası Bir Sorun Haline Gelmesi", https://turksandarmenians.marmara.edu.tr/tr/ayestefanos-ve-berlin-antlasmalariyla-ermeni-meselesinin-uluslararasi-bir-sorun-haline-gelmesi (Alınma Tarihi: 06.01.2021). 
Ermenilerin Rus amaçları doğrultusunda Kafkasya ve Anadolu'da kullanılmasının yanı sıra Türkistan coğrafyasında da aynı yöntemin takip edildiği ve önce Ermeni nüfusun bölgeye göç ettirildiği ve Rusya için bir toplumsal dayanak oluşturulmaya çalışıldığı anlaşılmaktadır. 19. asrın ikinci yarısından 20. asrın ilk çeyreğine kadar bölgede bir Ermeni topluluğu oluşturuldu ve önce Çarlık yönetimi, daha sonra da Bolşevikler bu topluluğu kendi siyasetleri doğrultusunda kullanmayı sürdürdü. Çarlık Rusyanın geleneksel "Ruslaştırma" siyasetinden şüphesiz Ermeniler de paylarını alıyorlardı. Bu sebeple milliyetçi Taşnak Partisi taraftarı olan örgütlü Ermeniler Çarlığa karşı harekete geçerek terör eylemleri gerçekleştirdiler. Buna rağmen Osmanlı Devleti'nin yıkılacağı beklendiğinden Ermeniler aracılığıyla Doğu Anadolu'nun tamamını elde edebileceğini düşünen Rus Çarlığı içerde Ermenileri kontrol altında tutmaya çalışırken dışarıda onlar adına taleplerde bulunmayı sürdürmekten geri durmadi ${ }^{8}$. Bu husus, I. Dünya Savaşı'nın başlamasından hemen sonra Osmanlı topraklarının paylaşılması için başlayan gizli paylaşma anlaşmalarında ortaya konulan Rus taleplerinde önemli bir rol oynamıştır. Nitekim Sykes-Picot Antlaşması Ermeni taleplerinde ileri sürülen bölgenin Rusya'ya bırakılmasında bir mutabakata varıldığını göstermektedir. Ancak 1917 Bolşevik İhtilali işleri tamamen farklı bir noktaya taşımıştır ${ }^{9} .1917$ Şubat ve Ekim gelişmeleri sonunda Çarlık rejimi ortadan kalktı ve Rusya'da iç savaş baş gösterdi. Bir "milletler hapishanesi” durumundaki Rusya'da milliyetçilik yükselişe geçti ve tabiatıyla Türkistan coğrafyasında öteden beri var olan istiklal talepleri bir milli kurtuluş mücadelesine dönüştü. Çarlığı devirerek ülkeye egemen olmaya çalışan Bolşevikler, bu milliyetçi akımları çeşitli taktiklerle önce yanlarına almaya çalıştılar ve sonunda da onları yasadışı ilân ederek yok etmeye yöneldiler ${ }^{10}$. Sovyet tarihçiliğinde "Basmacı Hareketi" olarak adlandırılan Türkistan'daki Milli Bağımsızlık hareketine karşı Bolşevikler ciddi bir askeri ve siyasi kampanya yürütmüşlerdir. İki taraf arasında gerçekleşen bu çatışma, 1917-1930 yılları arasında bölgede 19. asrın ortalarından itibaren gelişmeye başlayan Türk entelektüel sınıfinın ortadan kalkmasıyla sonuçlandı. Bu noktadan bakıldığında yeni "Sovyet toplumu"nun inşası sürecinde Türkistan'ın ekonomik, sosyal ve po-

8 Özşavlı, agm., s.262.

9 Tuncer Çağlayan, "Büyük Ermenistan Projesi ve İngiltere”, Atatürk Araştırma Merkezi Dergisi, C XV/S.44, Temmuz 1999, s. 513-528, s. 515.

10 Bu konuda bk., Derviş M. Kılınçkaya - Talas Omarbekov -, Mirzahan Egamberdiyev, "Sovyetler Birliği Döneminde Yıldırma Politikasının Bir Unsuru Olarak “Türkçülük” Suçlaması”, Cumhuriyet Tarihi Araştırmalan Dergisi CTAD, Y1l 15, S. 30, (Güz 2019), s. 1-27. 
litik hayatının Marksist-Leninist kavramlar ve Bolşevik ideolojisi çerçevesinde yeniden kurgulanması, milli hafizanın silinmesi ve yeniden yaratılması maksadıyla Sovyet tarihçileri bu bölgeyle daha yoğun bir biçimde ilgilendiler. Tarihçilik açısından bu sürece bakıldığında Taşnakçı Ermenilerin Türkistan'da Sovyet iktidarının kurulmasında üstlendiği rolün günümüze kadar yeterince ele alınmadığı rahatlıkla söylenebilir. Bu çerçevede Bolşeviklerin, Taşnakçı Ermenilerle Türkistan coğrafyasındaki siyasi ve askeri hareketlerde yürüttükleri işbirliği ve bu hareketler çerçevesinde ortaya çıkan zulüm ve katliamlar Türkistan tarihi ile ilgili çalışmalarda değerlendirilmemiştir. Türkistan tarihinin 1917-1922 yılları arasındaki bu çatışma dönemi genellikle Sovyet ve Rus teorileri çerçevesinde objektif olmayan bir tarza ele alınmıştır. Bu çalışmada, Çarlık döneminden Bolşevik yönetimine Türkistan'da Ermenilerin "inşa edilmiş düsmanlık" psikolojisinden yararlanmak maksadıyla gerçekleştirilen Ermeni iskânı ile ortaya çıkan diasporanın eylemlerinin çeşitli boyutlarının ele alınması ve Bolşeviklerin, Türkistan'ın Sovyetleştirilmesinde Taşnakçı Ermenileri kullanması sorunu bir tarihi problem olarak ilk kez arşiv belgeleri çerçevesinde incelenmektedir.

\section{Türkistan'ın 1917-1922 Yılları Tarihinin Araştırılmasına Genel Bir Bakış}

Türkistan'ın 1917-1922 yılları arasındaki meseleleri Sovyet tarihçiliğinde farklı açılardan incelenmesine rağmen bunların hiçbiri Taşnakçı Ermenilerin Sovyet iktidarının kurulmasında ve Bolşeviklerin bölgedeki politikalarının şekillenmesinde üstlendikleri rolden bahsetmemektedir. Neredeyse bugüne kadar yapılan tüm çalışmalarda Bolşeviklerin Türkistan'da ortaya koydukları medenileştirme (sivilize) politikasından ve Sovyetiktidarının kurulmasıly başlayan ekonomik gelişmeden söz edilmekte, ancak bölgede izlenen iskân politikalarından hiç bahsedilmemektedir. Keza, SSCB’nin kuruluş yıllarından itibaren Türkistan coğrafyasında yürütülen milliyetler siyasetine çok kısaca temas edilerek geçiştirilmektedir. Ancak SSCB'nin dağılmasından sonra arşivlere ve arşiv belgelerine erişebilme imkânının ortaya çıkmasıyla bu tür meseleleri aydınlatma ve açıklama şansı da ortaya çıkmış bulunmaktadır. Dolayısıyla, Ermenilerin Bolşevikler tarafindan kullanılması, özellikle Taşnak kuvvetlerinin bölgedeki faaliyetleri ve Türkistan Türklügüne karşı tutumlarının mahiyeti ve tarafların birbirlerini nasıl algıladıklarını daha anlaşılabilir şekilde ortaya koymak mümkün görünmektedir. Ayrıca bölgede Sovyet iktidarının şiddet kullanarak kurulması hususundaki gelişmelere ışık tutulabilmesi de mümkün olabilecektir. 
Konuyla ilgili olarak yapılan çalışmaların arasında Şuhrat Salamov'un (Şuhrat Barlas) kitabı ile A. Ş. Kıdırbayev'in çalışmaları başta gelmektedir. Ş.Salamov, Özbekistan ve Rus arşivlerinde yaptığı incelemelerde 1880-1922 tarihleri arasında Güney Kafkasya ile Türkistan bölgesinde bulunan Taşnakçı Ermenilerin Türkistan'daki kanlı izlerini, kıtlı döneminde Ermenilerin bölgede soykırım mahiyeti taşıyan faaliyet ve politikalarını ele almaktadır ${ }^{11}$. A. Ş. Kıdırbayev ise Kazakistan arşiv belgelerine dayalı olarak 1917-1921 tarihleri arasında Türkistan'daki Ermeni diasporası ile Taşnak askeri birliklerinin bölgedeki yağmacılık faaliyetlerini ortaya koymaktadır ${ }^{12}$. Her iki araştırmacı da Türkistan Genel Valiliği (1917'de Türkistan Muhtariyeti) sınırları içindeki bölgelerde bilhassa Güney ve Güney-Doğu Kazakistan'daki Taşnakçı Ermenilerin faaliyetlerini incelemektedirler.

Ayrıca İ. B. Boçkaryova ile Yu. A. Lısenko Türkistan'ın Sovyetleştirilmesiyle ilgili olarak bölgede daha sonra yeni kimlik anlayısıının oluşturulması, 1917-1921 tarihleri arasında Türkistan'daki Milli Mücadele, Türkistan Sovyet Sosyalist Cumhuriyeti’nin kuruluşu ve Türkistan Merkezi İcra Komitesi’nin faaliyetleri hakkında genel bilgi vermektedirler ${ }^{13}$. O. Yu. Kuznetsov, Ermenilerin XX. yüzyılda dünya çapında yürüttükleri terör siyasetini ele alarak, günümüzdeki bu mesele ile fikir çatışmalarından bahsetmekte ve Ermeni terörizm tarihi ile ilgili literatürün tarihî ve bibliyografik incelemesini yapmaktadır. Bunun yanı sıra arşiv malzemelerine dayanarak Ermeni terör suçlarının ceza kanunu açısından değerlendirilmesi sorunlarını, adli analiz sonuçlarının mahiyetini ve kronolojisinin yorumlanmasına etkisini değerlendirerek, $\mathrm{XX}$. yüzyılın son çeyreğinde $\mathrm{ABD}$, Sidney, Bağdat, Beyrut ve SSCB'deki Ermeni siyasi terörizminin kökenlerini ortaya koymuştur ${ }^{14}$.

SSCB'nin kuruluş döneminde Türkistan'ın Sovyetleştirilmesi meseleleri ve bölgedeki Türk-Müslüman halklarının Milli kurtuluş mücadelesi, ilk olarak

11 Şuhrat Salamov (Barlas Şuhrat), Turkestan i Tujny Kafkaz XIX-XX vv. Daşnaki ot Fergan do Karabaha, Taşkent 2015.

12 A. Ş. Kıdırbayev, "Armyanskaya Diaspora i Daşnaktsyutun v Turkestane. 1917-1921 Godı". Vostoçny Arhiv. No. 2 (28), Moskva: İnstitut Vostokovedeniya Rossiyskoy Akademii Nauk, 2013, s. 32-39.

13 İ. B., Boçkaryova - Yu. A. Lısenko "Natsionalnıy Vopros" i Stanovleniye Sovetskoy Vlasti v Turkestane (1917-1921). Vestnik Tomskogo Gosudarstvennogo Universiteta. No. 429, Tomsk 2018, s. 110-112.

14 O. Yu. Kuznetsov, Istoriya Transnatsionalnogo Armyanskogo Terrorizmav XX Stoletii, İstoriko-Kriminalistiçeskoye İssledovaniye, II İzdaniye s Dopolneniyami, Moskva 2015. 
o döneme doğrudan şahit olanlar tarafından ele alınmıştır. 1920'nin sonu ile 1930'ların başlarında yayınlanan G. I. Safarov, askeri analist P. T. Alekseenkov ve F.Illyutko'nun eserlerinde, Türkistan bölgesinde Bolşevik sisteminin kuruluşu ile "Basmacı Hareketnin" tarihi incelenmiştir ${ }^{15}$. 1940'da yayınlanan çalışmalarda Türkistan'daki Milli Mücadele hareketi Sovyet araştırmacıları tarafindan genel olarak"sömürücü sinf hareketi", "burjuva milliyetçi ayaklanması", "geniş bir sosyal tabandan yoksun olan ve diş güçlerin desteğine güvenenler" olarak vasıflandırılmış, "sonuçta silah ve propaganda yardım ile yapılan bu isyanlar büyük kayıplara uğradı ve başarısız oldu" şeklinde değerlendirmeler yapılmıştır ${ }^{16}$. A. M. Aminov ve A. H. Babahojaev, Sovyet sisteminin Türkistan'da kurulmasına karşı Milli Mücadele'nin güçlenmesi ile bu mücadelenin yönetimi üzerinde başta İngiltere'nin ve daha sonra uluslararası örgütlerin etkisi olduğu iddiasını dile getirmektedirler. $\mathrm{Bu}$ araştırmacılar çalışmalarında İngiliz dış politikasının temel yönlerini kaynaklara dayanarak yeni bir yaklaşımla anlatmışlardır ${ }^{17}$. A. V. Stanişevskiy (Nialo Aziz) ve P. P. Nikişov'un Basmacı hareketi ile ilgili çalışmaları oldukça ilginçtir ${ }^{18}$. Çalışma, 1917'den 1920'li yılların ortalarına kadar şimdiki Kırgızistan topraklarında Basmacı hareketinin gelişmesine hasredilmiştir. Ş. Taşliyev ve M. Yazykova Türkmenistan'da Basmacılı̆̆ı̆ oluşumu ve gelişmesinin çeşitli safhalarını incelemişlerdirr ${ }^{19}$. N. Timofeev ve M. Ahinjanov, "Kazahskaya SSR" adlı çalışmada, Kazakistan'daki iç savaşın bir parçası olarak İngiltere ve Fransa'nın etkisinde ortaya çıkan Basmacı hareketi ile beyaz asker birliklerinin arasındaki bağlantıya dikkat etmiştir ${ }^{20}$.

15 G. I. Safarov, Kolonialnaya Revolyutsiya (Opt Turkestana), Moskva, 1921 s. 63-89, G.İ. (Safarov 1924), Osnov Leninizma, Leningrad: Priboy, 1921, s. 24-29; P. T. Alekseenko, Çto Takoye Basmaçestvo? Taşkent 1931, s. 6; P. T. Alekseenko, Krestyanskoye Vosstaniya v Fergane, Taşkent 1931, s.21, F. İlyutko, Basmaçestvo v Lokaye, Moskva 1929, s. 59-156.

16 A. A. Maksimoviç, Basmaçestvo: "Vzglyad Sovetskih İssledovateley. Kazakhstan i Stranı SNG: 20 Let İntegratsii v Globalnıy Kulturno-İstoriçeskiy Kontekst” (Sbornik Materialov Mejdunarodnoy NauçnoPraktiçeskoy Konferentsii, Posvyaşonny 20-Letiyu Nezavisimosti Respubliki Kazahstan i 20-Letiyu Obrazovaniya SNG). II. Tom., Almat1 2011, s. 110-126.

17 A. M. Aminov - A. H. Babahojayev, Ekonomiçeskiye Posledstviya Prosoyedineniya Sredney Azii k Rossii, TaşkentUzbekistan 1966.

18 Aziz Nialo, Oçerki Grajdanskoy Voyn v Kirgizii i Sredney Azii, Frunze 1941; P. P. Nikişov, Borba s Basmaçestvom na Nuge Kirgizii, Frunze 1957.

19 Ş. Taşliyev, Ustanovleniye i Uproçneniye Sovetskoy Vlastiv Turkestane, Aşhabad 1957. Yazykova M. (1957). Borba za Ustanovleniye i Uproçneniye Sovetskoy Vlasti v Zapadnom Turkmenistane. Aşhabad.

20 N. Timofeev - M. Ahinjanov, Kazahskaya SSR, Gospolitizdat 1941, s. 36-37.

Belleten, Nisan 2021, Cilt: 85/Sayı: 302; 227-277 
1950’lerin ikinci yarısında yerel ve merkezi arşivlerden konuyla ilgili yeni arşiv materyalleri çalışmalara dahil edilmeye başlandı. $\mathrm{Bu}$ da konuyla ilgili bilgilerin nisbeten artmasını ve araştırmayı birincil kaynaklarla zenginleştirmeyi mümkün kıldı. Ayrıca Stalinist baskı döneminde Türkistan'daki Milli Mücadele hareketine karşı savaşan bazı Rus ve Ermeni askeri liderlerin isimleri de bu vesileyle ortaya çıkmaya başladı. 1960-1970 yılları arasında M. İrkaev Türkistan'daki Basmacı hareketi ile ilgili çok sayıda çalı̧ma yürütmüştür. Yazar, Basmacı hareketinin yaygınlı̆ını, sebeplerini ve bastırılmasını Sovyet tarih yazımı yöntemi ile ele almışıı'²1. M. İrkaev'in çalışmalarında, Basmacı hareketinin iç ve dış koşulları, toplumsal tabanının özellikleri ve "yeni ekonomik program"ın başlamasının önemli sebepleri Sovyet gözü ile anlatılmaktadır. Yazar, Basmacı hareketinin toplumsal temelini "feodaller, din adamlar, memurlar, zengin ve yeni burjuva unsurlar" duğunu öne sürmektedir. Daha sonraki tarihlerde Yu. A. Polyakov ve A. I. Çugunov, Orta Asya Basmacı hareketi çalışmalarına önemli bir katkıda bulundular. "Basmacılığın Sonu" adlı bu çalışmada yazarlar, 1917-1931 yıllarında Orta Asya'daki Basmacı hareketinin kökenlerini ve gelişimini, Tacik ve Özbek SSC'de İbrahim Bek önderliğindeki ana Basmacı gruplarının ortadan kaldırılışına kadar olan süreci de dahil ederek ele aldılar ${ }^{22}$.

Araştırmacılar, 1970'lerin sonlarında ve 1980'lerin başında Afganistan'da ortaya çıkan siyasi durumla bağlantılı olarak Basmacı hareketinin gelişim tarihine yeniden ilgi duydular. B. V. Lunin ve E. Yusupov gibi yazarlar, 1920-1930'larda Türkistan Basmacılığını, 1980'de Afganistan'daki mücahidlerin eylemleriyle karşlaştıran bir dizi tarihsel çalışmalar yaptılar ${ }^{23}$.

Sovyet dönemi tarih yazımında; devlet ideolojisinin mutlak egemenliği, arşiv belgelerinin içeriğinin açıklanmasında devlet sansürü konulması, toplumsal konulardakiçalışmalarda komünistideoloji çerçevesinde yorum yapma zorunluluğu ve kaygısı çok açıktır. Bu sebeple de Basmacı hareketiyle yakından ilişkili olan Taşnakçı Ermenilerin Türkistan'daki faaliyetlerini sağlam bir metodolojinin temel niteliği olan "objektiflik" çerçevesinde ele alan eserlerin yazılması mümkün olamadı. Sovyet tarihyazımı, Basmacıları "kendi menfaatlerine göre hareket eden ve bu yönde çaba harcayarak Bolşeviklerle iş̧birlĭgi kurmayn kabul etmeyen asiler" olarak tanımlamaya gayret etmiştir. Sovyet tarihçileri, Basmacı hareketini halka karşı

21 M. İrkayev, İstoriya Grajdanskoy Voyn v Tadjikistane, Duşanbe: Tadjıkgosizdat 1971.

22 Yu. A. Polyakov - A. İ. Çugunov, Konets Basmaçestva, Moskva 1976, s. 16.

23 B. V. Lunin - E. Yu Yusupov, Basmaçestvo - Orudiye Reaktsii (İstoriçeskiye Paralleli), Taşkent 1984. 
bir hareket olarak nitelendirdi ve Türkistan Komünist Partisi, Türkistan'daki tüm halkların iradesini ifade eden tek siyasi güç olarak değerlendirildi. Bu ögreti sistem tarafından resmi olarak yerleştirildi. Bu yaklaşımın Türkistan'da birliği teşvik eden manevi gücün yok edilmesine hizmet ettiği ve aslında sözkonusu tarihyazımının amacının da bu olduğu söylenebilir.

Sovyet sonrası dönemde, Türkistan'daki Basmacılığın temelleri ile özel olarak da bu makalenin temel sorunsalını oluşturan Taşnakçı Ermenilerin bu dönemdeki rolleri hakkında yeni araştırmalar yapılmadığını belirtmek gerekir.

Bu çalışmada, Özbekistan ve Kazakistan merkezi devlet arşivleri ile Rusya SosyalSiyasi Tarih Arşivi fonlarında bulunan belgeler kullanıldı. Bu fonlar içerisinde yer alan belgelerden önemli bir kısmı ise ilk defa kullanılmıştır. Araştırmada, Ermenilerin Türkistan'daki yerleşimlerinin tarihi, Çarlık Rusya'sı döneminden başlayarak Bolşevik yönetimi de dâhil olmak üzere Ermenilerin bölgedeki sosyal, ekonomik ve idari anlamdaki konumları ile bunların Basmacı hareketine karşı faaliyetleri, arşiv belgeleri ve konuyla ilgili araştırmalar ışığında değerlendirilecektir.

\section{Türkistan'da Rus İşgali ve Ermenilerin Bölgede Yerleşmesi}

Kazakistan topraklarının 18. yüzyıldan başlayarak 19. yüzyılın ikinci yarısına kadarki süreçte Rus işgaline uğramasının ardından bu topraklar üzerinden Türkistan'a doğru Sırderya işgal hattı açıldı. Bu süreçte Rus subaylar, yetkililer ve akademik inceleme heyetleri ilk etapta Ermenileri tercüman olarak kullandılar. Bunun yanı sıra, Rus işgali ilerledikçe idari sorumlular, Ermenilerin Türkistan topraklarına yerleşmesini teşvik ettiler. Yukarıda da ifade edildiği üzere Rus-Ermeni işbirliği işgallerde önemli bir rol oynamaktaydı. Böylelikle Ermeniler 1861'den itibaren Rus ordularıyla birlikte Hazar bölgesinden Türkistan’a doğru ilerlemeye başladılar. Türkistan bölgesinin işgal altına alınmasının ardından önce Türkistan Oblastı ve ardından 1865'de Taşkent merkezli Türkistan Vilayeti Genel Valiliği kuruldu. Bu valilik kanalıyla işgal altına alınan topraklarda siyasi ve ekonomik entegrasyon gerçekleştirmek amacıyla sosyal, hukuki ve idari açıdan genel bir düzen kurulacaktı. Bu şekilde Ruslaştırma politikası gerçekleştirilmiş olacaktı. İlk vali ise General Konstantin Petroviç Kaufmann'dı (1818-1882). Kaufman burada 20 yıl boyunca görev yapti² ${ }^{24}$

24 Hatice Kerimov, Türkistan Genel Valiliŭi'nde İdari Sistemin Oluşumu ve Gelişim Süreci (1865-1897), T. C. Istanbul Üniversitesi Sosyal Bilimler Enstitüsü Tarih Anabilim Dalı Genel Türk Tarihi Bilim Dalı Doktora Tezi, İstanbul 2019. 
1867'de Çarlık yönetimi Kaufmann’ın idaresi altında Türkistan'da bir dizi idari reform gerçekleştirdi. Gerçekleştirilen reformlar çerçevesinde Taşkent merkez olmak üzere Türkistan Genel Valiliği bölgede yayılma politikası izleyerek yerli halkın içine sızmaya başladı. Merkezî yönetim tarafından bu politikanın başarılı olması için Genel Valilik idaresine sınırsız yetkiler verildi. Türkistan Genel Valiliğine Sırderya ve Yedisu Vilayetleri dâhil edildi. Özellikle Valiliğin ticari işleri ve dış politika yetkileri zamanla arttı. Bu yetkiler çerçevesinde bölgeye göç ettirilen Ermeniler Karabağ, Zengezur ve Batı Ermenistan'dan getirilerek Türkistan topraklarına yerleştirilmeye başlandı ${ }^{25}$. Türkistan'da 1867 ve sonrasında yayınlanan Turkistanskiye Vedomosti, Russkiy Turkestan, Turkistan Ulayatı (Vilayeti) gibi gazetelerde: "Ermeniler, hem ekonomik hem de kültürel olarak olağanüstü bir rol oynuyor" şeklinde haberler yayınlanmaktaydi ${ }^{26}$. Türkistan coğrafyasındaki ilk Ermeni yerleşimleri 1867 yllında Türkistan Genel Valiliği Rus askerleriyle birlikte Yedisu, Sırderya, Merv, Çardjuy, Semerkand, Taşkent ve diğer şehirlerde gerçekleştirildi ${ }^{27}$. Ermeniler Türkistan'da daha sonra başta Semerkand, Hokand ve Andican'da, bilahare genel-valiliğin yeni idari birimlerini oluşturan Aşkabat ve Fergana vadisine iskân edildi. Bu şekilde Türkistan bölgesine hareket eden Ermeniler, genellikle kentsel yerleşimlerin yakınlarında kurulan Rus askeri garnizonlarının istihkâm yerlerine yerleştiler. 1883'te Ermeniler, bölgedeki kentsel yerleşim noktalarında nüfusun hatırı sayılır bir bölümünü oluşturmaktaydılar ${ }^{28}$. Başlangıçta Ermenilerin bölgedeki yerleşmeleri geçici olarak görünüyordu. Ancak çok geçmeden onlar ticaretle uğraşmaya, çiftçilik yapmaya ve Rus askeri

25 1867'de Türkistan'ın işgalinden sonra Çar II. Alexander, Rusların ve Ermenilerin kitleler halinde yerleşmesine yol açan Türkistan Genel Valiliğinin kurulmasına dair projesini onayladı. Geniş bilgi için bk. ÖC MDA (Özbekistan Cumhuriyeti Merkezi Devlet Arşivi), Fon No. İ-717, Kayıt No. 1, Dosya No. 52, Sayfa No. 356.

26 KCMDA, Fon No. 44, Kayıt No. 1, Dosya No. 4144:1. Dosya Rusya İçişleri Bakanlı̆̆ı'nın Kazakistan'ın Yedisu bölgesi işgal idaresiyle yazışmalarından oluşmaktadır. Bu yazışmalara göre Eçmiadzinsk (Eçmiyazin, Ermeni Apostolik Kilisesinin ana manastırı. Ermenistan'ın Armavir bölgesi, Vagarşapat şehrinde bulunmaktadır) Ermeni-Gregoryen Katolik Patriği, Rusya İçişleri Bakanlığı önünde, Nahçivan-Besarab ve Astrahan Ermeni-Gregoryan kiliselerinin bölgesel yapısını değiştirilmesi gerektiğini öne sürmüştür. Bunun için Rus idaresi, Türkistan Genel Valisine Ermenilerin kişi sayısı, kiliseleri ve din adamları hakkında istatistik bilgileri toplama emrini vermiştir.

27 P. P. Litvinov, Gosudarstvenno-Religioznye i Etnokonfessionalnyye Otnoşeniya v Turkestane v 1865-1917 Godah. Po Arhivnım Materialam, Dissertatsiya Doktora İstoriçeskih Nauk, Moskva 1997.

28 E. A. Gluşenko, Rossiya v Sredney Azï. Zavoyevaniya i Preobrazovaniya. Çast 2. Ustroyeniye Kraya, Tsentropoligraf, Moskva 2010, s. 27. 
birliklerinde görev almaya başladılar. Daha sonra da ailelerini yanlarına getirerek kendi evlerini inşa ettiler ${ }^{29}$.

19. asırda Rus işgali esnasında Kazakistan'ın Batı bölgesi ile Sırderya'nın yukarı kısımlarına doğru Rus askeri garnizonları kuruldu. Bu garnizonlar arasında Fort-Şevçenko (Mañgışlak) Rus işgal politikasında önemli bir yer oldu. 1846'da, Hazar Denizi'nde Rusya'nın askeri karakolu olan Mangışlak yarımadasında üç savunma kulesi ile Novopetrovsk surları kuruldu. Bu askeri garnizon 1857'de Fort Aleksandrovski olarak yeniden adlandırıldı. Belgelere göre bu bölgenin karayolu bağlantısı zor, sadece deniz yoluyla iletişimi olan, hatta Ekim'den Nisan'a kadar kara yolları ile posta bağlantısı kapalı kalmaktaydı. Novopetrovsk komutanı İ. Uskov'un kızı Mañgışlak hatıralarında, "Küu̧ük bir taş kilisesi, bir komutan evi, bir gardiyan, bir hastane ve alt rütbeleri ve subaylan barndırmak için birkaç taş kanatl kale bulunuyordu. Kalenin yakınnda, dağm altında birkaç Ermeni dükkân var ve bozkır etrafinda yeşillĭgi olmayan bir bölge” olarak kaydeder. Kalenin yakınında Slobodskoy adı taşıyan bir Ermeni yerleşkesi kuruldu ve burada 01 Ekim 1874'te yapılan kayıtlara göre 88 Ermeni ikamet ediyordu ${ }^{30}$.

Hazar kıylarına Rus askerleriyle birlikte gelen ilk Ermeni yerleşimciler arasında çoğu kamu hizmetine giren ve ticaretle uğraşarak ekonomik faaliyetlerde bulunan eğitimli insanlar bulunmaktaydı. Ermeniler, Türkistan'daki yerli halkın gelenek ve göreneklerini, yerel Türkçeyi ticari yeteneklerini de kullanarak kısa zamanda öğrendiler ve Ruslarla yerli halkın arasındaki iletişimi kurmada aracılık rolünü üstlendiler. Rus işgal politikasına hız kazandıran Trans-Hazar demiryolunun, gümrük ve sınır direklerinin, kiliselerin ve camilerin, Rus okulları ile hastanelerin, özel evlerle devlet kurumlarının inşasında Ermenilerin aktif bir şekilde yer aldıkları özellikle belirtilmelidir. Novopetrovsk tahkimatında havariler (Pyotr ve Pavel''in onuruna Pyotr ve Pavel adına bir kilise inşa edildi. Yerel tarihçilerin, müze personelinin ifadelerine ve belgelere göre kilise, Ermeniler tarafindan Astrahan Ermeni tüccarlarının parasıyla Rusların Hive zaferinin 20. ylldönümü onuruna 1893 başlarında inşa edilmişti ${ }^{31}$. Bu durum da bölgedeki Rus işgali

29 KCMDA, Fon No. 85, Kayit No. 1, Dosya No. 87, s. 7-9.

30 KCMDA, Fon No. 44, Kayıt No. 1, Dosya No. 810: 1-4. Bu dosyada Türkiye topraklarından gelerek bat1 Kazakistan ile Yedisu bölgesine yerleştirilen Ermenilere maddi destek sağlamak için para toplandığına dair raporlar mevcuttur. Çarlık yönetimi tarafindan 1897-1898'de açılan dosya 90 sayfadan ve aktarılan para makbuzlarından oluşmaktadır. Yerleştirilen Ermenilerin sayısı hakkında kesin bir kayıt yoktur.

31 KCMDA, Fon No. 41, Kayit No. 1, Dosya No. 258, s. 1-2.

Belleten, Nisan 2021, Gilt: 85/Say1: 302; 227-277 
esnasında Ortodoks ve Gregoryen kiliseleri arasında sıkı bir bağlantı kurulduğu ve iki kurumun birbirini desteklediği anlamına gelmektedir.

1897'deki ilk Rusya genel nüfus sayımına göre, Trans-Hazar, Semerkant ve Fergana vadisinde yaşayan toplam Ermeni sayısı, beş bin kişiye ulaşmışts ${ }^{32}$. Rus Ordusu Generali B. Litvinov, Türkistan Genel Valisi K.P.Kaufman'ın 1910 yllında toplanarak yayımlanan "Kaufman Koleksiyonu" adlı eserinde: "Rus askeri birlikleri Türkistan'a geldiğinde Ermeniler onlarla beraber geldi... küu̧ük dükkanlar açt, Rus köylïlerinin sayısı arttktan sonra... ulaştırma ofisleri, fabrikalar, kiliseler, okullar açıld ve her yerde Ermeniler, Ermeniler ve Ermeniler çoğaldı. Ermeni tüccarlar Tatar tüccarlarn yerine geçti, hatta terzihane işlerinde kurnazhkta Yahudileri bile geçti... Kisacası birahane sahipleri onlar oldu, Rus ve Sart'larn ${ }^{33}$ arasında çok akıllıca konumlanmış özel Ermeni mahallelerini oluşturdular" demekteydi ${ }^{34}$. Yine aynı eserde: "1913'te, Fergana vadisinin Ermeni nüfusu 3.292 kişiydi. Ermenilerin sayıs gittikçe yerleşik hale geliyor ve refah giderek arthyor. ErmeniGregoryen bölge okullarn açllyor. Türkistan Bölgesi şehirlerinde apartmanlar ve restoranlar, onlar tarafindan kurulan dükkânlar açlmaktadrr. Birrsok Ermeni, devlet ve askeri görevlerde bulunmaktadr ${ }^{935}$. Arminius Vambery hatıralarında Ermeniler hakkında şu bilgiler yer almaktadır: "Ayrica Gầuur Qalası (kâfirlerin şehri) adı verilen geniş alanda taş binalarnın kalntılan var. Illk başta, gâvur kelimesi gebralar anlamm veya tarih öncesi ateșe inananlara

32 R. G. Nazaryan, Armyane Samarkanda, Moskva 2007, s. 17.

33 Sart sözcüğünün anlamına dair çeşitli münakaşalar olmakla birlikte bazı kaynaklar "Sart" kelimesinin Sırderya nehrinin eski adı "Yak-Sart'tan" geldiğini söylemektedir. Yani "Sırderya kenarına yerleşen halk" anlamını vermektedir. Genelde Sart'lar ticaretle ilgilendiği için göçebeler arasında "uyanık", "hırsız", "üçkâğıtçı" olarak algılanmaktadır. Geniş bilgi için bk. Ş. S. Kamoliddin, Eşo Raz o Termine Sart. Sogdiyskiy Sbornik. Noveysize, Issledovaniya po Istorii i Kultury Sogda v Uzbekistane, Saarbrücken 2017, LAP, s. 17-30.

34 "Turkestanskiy Sbornik" (Türkistan Koleksiyonu), toplam 594 ciltlik bir kaynak koleksiyonudur. Koleksiyonun oluşturulması Türkistan genel valisi K. P. Kaufman'ın emriyle Türkistan'ın Çarlık Rusyası tarafindan işgalinden sonra 1867'de başlatıldı. Türkistan Koleksiyonu önce St. Petersburg'da ve daha sonra Taşkent'te sürdürüldü ve Türkistan'la ilgili Rusça ve Batı dillerinde yazılmış farklı materyallerin toplanmasıyla oluşturuldu. Türkistan'ın işgalinden başlayarak 1917'ye kadar olan dönemi kapsayan raporlar, derlemeler, emirler, talimatlar, Rus ve yerli halkın kültürü, adet ve örfleri, İslam dini ile ilgili eğitim meseleleri hakkında raporlar, Rus-Yerli (Tuzem) okulları ile ilgili istatistik ve değerlendirme raporları, gazete bilgileri, kitap özetleri, istatistiki veriler vs. gibi zengin tarihi malzemeyi içermektedir. Günümüzde bu koleksiyonun tamamı Özbekistan Cumhuriyeti Milli kütüphanesi’nde bulunmaktadır. Kaufmanskiy Sbornik, III. Tom., Taşkent1910, s. 29-31.

35 Kaufmanskiy Sbornik, Taşkent 1910, s. 36.

Belleten, Nisan 2021, Cilt: 85/Sayı: 302; 227-277 
söylendiğini düşündüm, ancak benim için sürpriz oldu, tüm Orta Asya'da bu adla Ermeniler veya daha doğrusu Nasturilerin ifade edildiğini duydum ${ }^{\prime 36}$.

Bu çerçevede bölgede iskân edilen Ermenilerin ticari alanda önemli yer edindikleri anlaşılmaktadır. Mañgışlak bölgesinde iskân edilen Ermeniler esas olarak tüccarlar ve zanaatkârlardan oluşuyordu, onların bir muhtarı ve bir dini okulu vardı. $\mathrm{Bu}$ yerleşimde Astrahan Ermenilerinin yanı sıra Tiflis Ermenileri de burada ticaretle uğraşıyordu ve bunlar Mañgişlak'taki Rus askeri birliklerine yiyecek, giyecek ve alkol tedarik ediyordu ${ }^{37}$. Türkistan Genel Valiliğine bağlı Trans-Hazar bölgesine vali olarak tayin edilen A. N. Kuropatkin" ${ }^{38}$ de "Ermeniler, ticaret yeteneklerinde Yahudilerle rekabet edebilirler. Ermeniler, faaliyetlerini Rusya'dan Türkistan'a transfer ettiler. Ermeniler, Rus kanıyla işgal edilen bu topraklarda iç ve diş ticaretle birlikte pamuk üretimini ele geçirmeyi başardı. Iran ile Trans-Hazar bölgesinde ticaret ağırlkhl olarak Ermenilerin elindedir. Aşkabad'ta ticaret ellerinde. Kafkasya'daki petrol işinin önemli bölümü Ermenilerin elindedir. Hazar Denizi'nde çeşitli şekillerde yapılan balıķılık da uzun zamandan beri Ermenilerin eline geçmiş vaziyette..." demekteydi ${ }^{39}$.

Bakü ve çevresinde büyük petrol yatakların olduğunun anlaşılması diğer birçok etnik unsur gibi Ermenilerin zaten var olan ilgisini buraya çekti. Bakü'nün en zenginleri ise Ermenilerdi. Rusya'nın açık desteğini almış olan Ermeniler hem kültürel hem de ekonomik açıdan Müslümanlardan çok daha üstün bir konuma gelmişlerdi. 1872 yılında gerçekleşen Petrol İmtiyazları İhalesi'nde Türkler ancak \%5 bir pay alırken Ermeniler bunun on mislini almışlardı. Bakü'de bulunan 167 çoğu küçük petrol firmasının 49’u Azerbaycan Türklerine ait iken 55 orta ve büyük çaplı petrol işletmesi zengin Ermeni ailelerinden Mirzoevler, Mailovlar, Liazonovlar, Aramyanlar, Tavetosyanlar ve Mantaşyanlar'a aitti ${ }^{40}$.

Pamuk üretiminde dünyada ikinci sıra yer alan Özbekistan toprakları oldukça önemliydi. Özbekistan'da pamuk üretimi ve ticareti uzun bir geçmişe sahiptir.

36 Armini Vambery, Puteşestviya po Sredney Azii, İzdaniye II. Moskva 1874, s. 68-69.

37 KCMDA, Fon No. 44, Kayit No. 1, Dosya No. 810, s. 16-18.

38 Aleksey Nikolayeviç Kuropatkin, General, teşkilatçı yeteneklere sahip olan ve 1898-1904 yıllarında Savaş Bakanlığı yapmış ve Rus ordusunun gelişimi için büyük başarılar elde etmiştir. Kuropatkin’in Rus ordusunun geçmişi ve geleceği hakkındaki görüşleri ilginçtir. Bunları 1910'da yazdığı çalışmalarında ana hatlarıyla belirtmiştir. 1886'da Çar Alexander III tarafindan "Türkistan bölgesinin yönetimi projesi" nden dolayı ödüllendirildi. Geniş bilgi için bk. A. Şarov, Zabıtıy General Kuropatkin, Kommunist Voorujonnh Sil. No.12, Moskva, 1991 s. 64.

39 A.N. Kuropatkin, Russkaya Armiya, İzdatelstvo Poligon, Sankt-Petersburg 2003, s. 7-8.

40 Mustafayev, agm., s. 536.

Belleten, Nisan 2021, Gilt: 85/Say1: 302; 227-277 
Arkeolojik bulgulara göre Özbekistan'da 5-6. yüzyıldan beri yapılmakta olan pamuk tarımı bölgede Rus işgal idaresinin kurulması ile birlikte pamuk tarımına daha fuazla önem verilmiş ve 20. asır başında üretim oldukça yüksek bir orana çıkmış ve pamuk Özbekistan’ın stratejik bir ürünü haline gelmiştir ${ }^{41}$.

1909'da sadece Trans-Hazar bölgesinde 14 pamuk temizleme fabrikasının altısı Ermenilere aitti. Merv şehrinde, iki fabrika Avetisov kardeşlere, üçü de merkezi Moskova'da olan fabrika sahibi Arzumanov tarafindan kiralanan şubeleri ise Ermeni Arunov'a aitti. Aşkabat'ta üç pamuk fabrikası, biri Ter-Mikirtıçev Ticaret Evi'ne, diğeri Ter-Teryants Kardeşler, üçü de Arzumanov Kardeşler adındaki Ermeni asıllı firma ve kişilere aitti ${ }^{42}$. Bunun yanı sıra Ermenilerin pamuk alım satımında aracılık yaptıkları gibi kendilerinin de bizatihi pamuk yetiştirdiklerinin altını çizmek gerekir. Aynı şekilde Atek, Serahs ve Trans-Hazar bölgesinde pamuk yetiştiren Ermeniler hakkında da kayıtlar mevcuttur ${ }^{43}$. Ermeni girişimcilerin pamuk hammaddelerinin ilk işlenmesi üzerinde yoğunlaştıkları anlaşılmaktadır. I. Dünya Savaşı'nın başlamasıyla 1915'te Türkistan'da pamuk temizleme fabrikalarının sayısı da hızlı bir şekilde arttı. Bunların 17'si Ermenilerin elindeydi ${ }^{44}$.

Diğer taraftan Ermenilerin iç pazar, dış ticaret ve sanayinin gelişimindeki rollerinin artması ve bir yönetim politikası olarak özellikle güçlendirildiklerinden, Çarlık yönetiminin bazı Ermeni karşıtı üst düzey yetkilileri giderek artan oranda "Ermeni unsurunun rolü" konusunda endişelerini dile getirmekteydiler. Nitekim Trans-Hazar eyaletinin genel valisi görevini yapan A. N. Kuropatkin Rusya Savunma Bakanlı̆̆ı'na gönderdiği mektubunda endişelerini: “Trans-Hazar bölgesi 10 ynl içinde bir Ermeni köşesine döndü. Bölgedeki Ermeniler Ruslar için son derece tehlikeli bir rakip gibi görünmektedir ve az saynda olsa bile Ermenilerin yeniden yerleştirilmesine izin verilmemesi gerekmektedir. 1890'da bölgede 2.893 Ermeni ve 4.815 Rus kaynt edilmistir. 01 Ocak 1894'e kadar bölgenin nüfusunun toplam 387.000 kişiden 3.438’i Ermeni ve 9.082'sini Ruslar olusturmaktadır" şeklinde ifade etmekteydi ${ }^{45}$.

41 Güçgeldi Bashimov, "Özbekistan Pamuk Sektörünün Rekabet Gücünün Belirlenmesi”, Türk Tarm ve Doğa Bilimleri Dergisi, 2015, 2(1), s. 99-104, s. 102.

42 A. A. Grigoryants, Armyane v Sredney Azii: (Vtoraya Polovina XIX - 1917), Erevan: Izdatelstvo AN ArmSSR, 1984, s. 157-159:

43 Obzor Zakasriyskoy Oblasti za 1909 God., Aşhabad: "Parovaya Tipografiya Gazetı "Aşhabad", 1911, s. 131-133.

44 Adres-Spravoçnik Zakaspiyskoy Oblasti za 1915 God, Aşhabad 1915, s. 82-84.

45 A. I. Maslov, Zavoyevaniye Ahal-Tepe, Sankt-Peterburg 1887, s. 17. 
Rus işgali ile birlikte Türkistan bölgesinde bir taraftan da Ortodoks misyonerlik faaliyetleri yürütüldü. Misyoner grupları arasında genellikle birçoğu Ermeni olan Hıristiyan tüccarlar da yer alıyordu. Ermeni tüccarlar ve zanaatkârlar sadece büyük şehirlerde değil, aynı zamanda Tupkaragan Körfezi (Batı Kazakistan’ın işgalinde önemli yere sahip olan yerleşke) olan illerde de yeni bölgelere yerleşmişlerdir. Kilise, Ermenilerin günlük hayatında her zaman çok önemli bir rol oynamıştır. Belgelere göre, 1852'de Astrahan Ermeni-Gregoryen Kilisesinin rahibi Miney Mkhitarov Mañgışlak'ta yaşayan Ermenilerin dini hizmetlerini yerine getirmek için görevlendirilmişti ${ }^{46}$. Ermeni tüccarları, aracılık yapan tercümanlarla birlikte hareket ederek, yerli halkın kültürel hayatını etkilemiştir. 1890'lı yılların başında, bölgenin tüm Ortodoks kurumları Astrahan piskoposluğunun yetkisi altındaydı.

Ermeni Gregoryen Kilisesi 19. yüzyılın ikinci yarısında, Rusya'da kendi mülkleri, diğer gayrimenkul ve sermayesi ile gelirinin kaynağını oluşturan tek kilise organizasyonu olarak kalmıştır. Bu haklar çerçevesinde Ermeniler bölgedeki misyonerlik faaliyetlerini kendine uygun bir şekilde yürütmüştür. Arşiv belgelerine göre Batı Kazakistan'daki petrol şirketlerinin kiliselerin inşasına büyük önem verdikleri ortaya çıkmaktadır. Bu belgelere göre, bu şirketler tarafindan Guryev'deki Ortodoks ve Gregoryen kiliselerinin inşasının ilerlemesi için maddi destek sağlama yanında kiliselerde görev yapacak din adamlarına aylık maaş olarak 170 ruble 40 kopek tahsisat ve ikamet için de bir daire verilmekteydi ${ }^{47}$.

Bu hususla ilgili olarak 12 Eylül 1913’te Rusya İçişleri Bakanlığına bağlı olan Manevi İşler Dairesi Başkanlığı, Ermeni-Gregoryenler hakkında bilgi toplaması için Yedisu bölgesinin valilerine, şehir polislerine ve kaymakamlara hitaben bir talimat gönderdi ${ }^{48}$. Bu talimat gereğince Yedisu bölgesinde yaşayan Ermeniler sayıldı. Vernıy (Almatı) şehri Polis Müdürlügünün 21 Ekim 1913 tarih ve 23245 sayılı belgesindeki kayıtlara göre bölgede sakin Ermeniler genel olarak subay, askeri doktor, elektrik teknisyeni ve ayakkabı tamircisi olarak çalışmaktaydı. Sayıları binden fazlaydı. Tanınmış olanları ise Andrias Semyonov Çergiştyants, Georgiy Minayeviç Arutyunov, Karapet Mikirtiçev Bodeyants, Garegin Sarakanov TerVartanyants ve Usen Avanegoviç Zelyants't1 ${ }^{49}$.

46 KCMDA, Fon No. 679, Kayıt No. 1, Dosya No. 165. "Emba-Hazar" Petrol şirketi. Kiliselerin ve din adamlarına maddi destek göstermek üzerine yazışmalar dosyası.

47 KCMDA, Fon No. 679, Kayit No. 1, Dosya No. 165, s. 1-3.

48 KCMDA, Fon No. 44, Kayit No. 1, Dosya No. 4144, s. 3

49 KCMDA, Fon No. 44, Kayıt No. 1, Dosya No. 4144, s. 6. 
Yedisu bölgesi Lepsi ilçesi yönetimi 14 Ekim 1913 tarih ve 4430 sayılı raporuna göre burada dört Ermeni aile, Prejevalsk ilçesi kaymakamının 6 Kasım 1913 tarih ve 23215 sayll raporuna göre iki Ermeni aile, Pişpek ilçesi kaymakamının 13 Aralık 1913 tarih ve 23235 sayılı raporuna göre ise bölgede 24 Ermeni ailesi mevcuttu $^{50}$. 1913 yll verilerine göre Yedisu bölgesinde toplam 41 Ortodoks kilisesi, 3 Gregoryan ve 77 Ortodoks okulu bulunmaktaydi ${ }^{51}$. Arşiv belgelerine göre 1912'de bölgede yaşayan Ermeni aile sayısı toplamda 283 idi ${ }^{52}$.

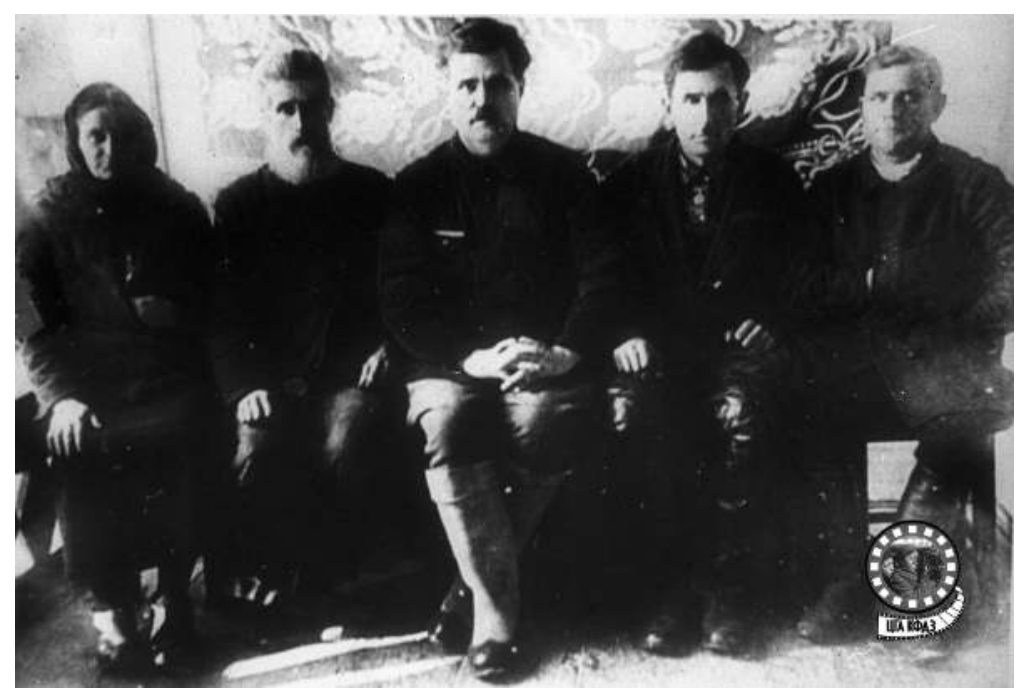

Resim 1: Kazakistan'ın Yedisu Bölgesindeki Ermenilerden Bir Grup.

20. yüzyılın İlk Çeyreği ${ }^{53}$

Rus işgal politikasında önemli yere sahip olan Guryev ${ }^{54}$ (şimdi Atyrau) 1640 yılında Rus askeri garnizonu olarak Türkistan hanlıklarıyla diplomatik ve ticari

50 KCMDA, Fon No. 44, Kayit No. 1, Dosya No. 4144, s. 7-11.

51 KCMDA, Fon No. 44, Kayit No. 1, Dosya No. 48806, s. 2-5

52 KCMDA, Fon No. 44, Kayit No. 1, Dosya No. 48940, s. 5-6

53 KC MDFFBSKA (Kazakistan Cumhuriyeti Merkezi Devlet Film ve Fotoğraf Belgeleri ile Ses Kayıtları Arşivi) Arx. 2-41-719.

54 1630'ların sonunda Moskova yönetimi, Yayık ve Emba kenarındaki balık alanlarını, zengin bir Yaroslavl ilçe elitinden gelen ünlü Rus ailesi Guryev'lerin tüccar ailesine bağışlamıştır. Yayık Nehrinin kenarlarında balıkçılık yapılmakta ve oradan avlanan kırmızı balık Rus pazarlarına satılmaktaydı. 1640'ta Guryev ailesi göçebeler, Don ve Yayik Rus Kozaklarının saldırılarına karşı korunmak için Ust-Yayitsky kasabasını (gelecekteki Guryev şehri) inşa ettiler. Böylelikle Guryev Batı Kazakistan 
ilişkileri sıkılaştırmak amacıyla kurulmuştu. Burası aynı zamanda Yayık (Ural) Nehri etrafindaki verimli toprakları ele geçirmeyi ve Hazar Denizi üzerindeki hâkimiyetini güçlendirmeyi amaçlayan Çarlık sömürgeci politikasının askeri stratejik merkezi rolünü oynamıştı. 1897 nüfus sayımı Guryev'de 9 bin 322 kişinin yaşadığını göstermektedir ${ }^{55}$. Trans-Hazarda minerallerin aranmaya başlandığ 1860'larda bölge ekonomisi gelişmeye başladı. Rus bilim adamları N.Severtsev ile I. Borisov 1857 'de, P. S. Pallas 1863'te, D. Kirpiçnikov 1874'te ve 1886'da Novakovskiy Batı Kazakistan'daki Matenqoja, Dossor, Eskene ve Karaşungîl yerleşkelerinde ve genel olarak Kazak bozkırlarında araştırma yaparak petrol kuyuları keşfettiler. Bu keşfe rağmen, coğrafi ve doğal zorluklar nedeniyle, petrol üretiminin gerçekleştirilebileceğinden emin olmadıkları hakkında Çar Aleksandr Nikolayeviç'e (1818-1881) raporlar gönderdiler ${ }^{56}$. Petrol, 1876'da Çeleken adasında ve Ruslar tarafindan Neftedağ ${ }^{57}$ adı verilen yerde bulundu. 1890'lı yıllarda da Rus ve Ermeni sanayicileri tarafından geliştirilmeye başlanan büyük petrol yatakları yanında çeşitli diğer cevherler de keşfedildi. Hazar bölgesindeki yeni petrol kaynaklarının işletilmesi meselesi, zengin Ermeniler de dâhil olmak üzere birçok yeni Rus iş adamlarını bölgeye çekti ${ }^{58}$.

1890'larda, Yayık-Jem Adasında petrol kaynaklarının varlığının yeniden ortaya konulması, Türkistan demiryolunun inşası gündemdeyken başladı. Daha sonra, 1892'de Rusya-Ural Demiryolu'nun inşası için emir verildiğinde; Dossor, Esken ve Karaşungîl yerleşkelerinin 7-9 metre derinliğe kadar bölgenin jeolojik özelliklerini inceleyen Nikitin önderliğindeki heyet aynı zamanda bölgede bulunan yeraltı servetlerini de keşfederek raporuna ekledi. Aynı yıl Sol-îletsk bölgesi avukatlarından Y. Lebedev'e Çarlık hükümetinin Batı Kazakistan'daki Kunkulak ilçesinin tuzlu toprakları hakkında özel bir çalışma yürütmesi için ilk izin verildi59 ${ }^{59}$ Bu imtiyazı 1892'de Dossor ve 1894'te Karaçağanak petrol bölgeleri için de elde etmeyi başaran Y. Lebedev, 1893 yllında ruhsatını N. N. Leman, Doppelmaer ve Grum-Grjimailo'ya sattı. Onlar 1898'de petrol araştırmaları yapma hakkını alan "Leman\&Co" şirketini kurdular. Böylece Kazak topraklarındaki kaynakları

topraklarındaki ilk Rus yerleşim yerlerinden biri oldu. Şehrin inşaatı 1662'de sona erdi. 17. yüzylın sonu ile 18. yüzylın başında Guryev büyük bir sınır kalesine dönüştü.

55 N.V. Alekseenko, Naseleniye Dorevolutsionnogo Kazahstana, Alma-Ata 1981, s. 47.

56 KCMDA, Fon No. 1479, Kayit No. 2, Dosya No. 711, s. 12-17.

57 Belgede Neftetau şeklinde geçmektedir.

58 I. Farmanov, Zapiski o Firme "Nasledniki G.M. Lianozova", Astrahan 1914, s. 110-112.

59 Ş T. Ş. aukenbayev, Uralo-Embenski Neftenosny Rayon, Alma-Ata 1960, s. 9-12.

Belleten, Nisan 2021, Cilt: 85/Sayı: 302; 227-277 
araştıran ilk petrol şirketi doğdu. Tanınmış petrol sahalarının çoğu bir imtiyaz olarak N. N. Leman adıı bir Yahudiye olan bu şirkete devredilmiş oldu ${ }^{60}$. Aynı dönemde Ural Vilayet yönetimi sınırları içindeki Guryev ve Kalmıkov bölgelerinde petrol kuyuları araştıılmışı ve bu çalışmaların sonucunda Guryev'deki şirketin mütevelli heyeti başkanlığında özel bir birim oluşturmuştu. Arkasından N. N. Leman

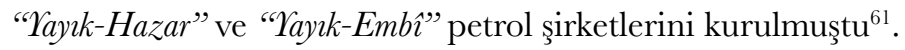

1873 yılında bir Ermeni tüccarı olan N. İ. Artemyev ilk olarak dökme petrol ve petrol kalıntılarının Bakü'den Astrahan'a tankerlerle taşınması işini organize etti. 1899'da A.I.Mantaşev (Manteşyan) ${ }^{62}$, Bakü'de "A.I.Mantaşev E C ${ }^{\circ}$ " adlı petrol şirketini kurdu ve 1879'da kurulan "Nobel Kardeşler Petrol Üretim Ortaklı̆g'nda hissedar oldu. A.İ.Mantaşev'in en büyük petrol üreticileri arasında yer alan üç erkek kardeşi vardı. Tüm Volga şehirlerinde Nobel teşebbüsünün temsilcilikleri ve marinaları vardı. 1881'de, "Nobel Kasabası" olarak bilinen büyük bir köy, Volga'nın sağ kıyısında Astrahan yakınlarında şehir düzeyine gelecek kadar büyümüştü ${ }^{63}$.

Kazakistan'ın Batı bölgesinde marinalar, petrol ürünleri tedariki için yeraltı boru hatları ile gazyağı depolamak için tanklar ve bu işle ilgili mekanik atölyeler açılmışır. 1880'li yllarda Ermenistan'dan bir başka büyük petrol endüstrisi milyoneri, petrol şirketi "Lianozov ${ }^{2}$ Co" yu kuran S. G. Lianozov (Lianosyan) ${ }^{64}$ isimli Ermeni zengini bölgeye büyük ölçüde yatırım yapt ${ }^{65}$. Ermeni petrol

60 Şaukenbayev, age., s. 17-19.

61 Şaukenbayev, age., s. 20.

62 Aleksander Mantaşev 20. yüzyılın başlarındaki Ermeni petrol zenginlerinden biri olup 1842'de 20. yüzyılın başlarında Ermeni kültürünün, siyasetinin ve ticaretinin önemli bir merkezi olan Gürcistan'ın başkenti Tiflis'te doğdu. Çocukluğunu ve gençliğini babasının tekstil işinde çalışarak kuzey İran'da Tebriz'de geçirdi. Daha sonra o zamanlar Ermeni diasporasının önemli kişilerinin de yer aldığı pamuk ve ticaretinin dünya merkezi olan Manchester'a (İngiltere) gitti ve burada yaşadı. Rus işgali sırasında Kazakistan'nın Batı bölgelerinde petrol işinde yer aldı. Mantaşev, Nobel Kardeşler, Rothschild kardeşler ve Rockefeller ailesi ile yarışarak, 20. yüzyılın en zengin insanlarıyla eşit bir servet elde etti. Misyonerlik politikasına yatırım yaptı, Rus okulların açılmasıyla bölgedeki Ermenilerin nüfuzunu arttırmak için çeşitli faaliyetlerde bulundu. Geniş bilgi için bk. Bedevyan Ruth. (2012). "Ascent to Wealth and Philanthropy of Alexander Mantashev", Armenian News Network / Groong, October 8.

63 KCMDA, Fon No. 679, Kaylt No. 1, Dosya No. 156, 1.

64 Russkiye Birjeviye Novosti 1914-1915, Petrograd 1915. S. 7.

65 Tüccar sanayici Lianozov ailesi tarihteki en büyük petrol üreticileri ve petrol şirketlerinin sahipleri olarak bilinmektedir. 19. ve 20. yüzyılın başlarında Rusya'nın en zengin ilk on kişisinden biri olan Lianozov ailesi, Ermenistan vatandaşları lehine olmak üzere hamiliğiyle bilinmektedir. Stepan Georgiyeviç Liazonov (Lianosyan) Moskova'da Ermeni ailesinde dünyaya geldi, Moskova Üniversitesi Hukuk Fakültesi'nden mezun oldu. 1901'de petrol işleriyle uğraştığı Bakü’ye taşındı, 1907'de “'G.M. Lianozov Oğulları Petrol Üretim Ortaklığı”nı kurdu. Liazonov 1917'de Bolşeviklerin iktidara gelmesiyle 
şirketleri Kazakistan'daki faaliyetlerini bu şekilde başlatmıştı. 1899'da ilk petrol kuyusu Karaçungul'da (Embinskiy, şimdi Jılıoy bölgesi, Batı Kazakistan) açıldı. Petrol şirketleri, Güney Emba'nın merkezinde petrol rezervlerinin varlığını ortaya çıardı. Daha sonra, 20. yüzylın başında işletmeye alınan Dossor ve Makat da dâhil olmak üzere çeşitli petrol yataklarının işletilmesine başladılar. Arşiv belgeleri, Batı Kazakistan'daki petrol satışlarında sürekli artış olduğunu göstermektedir. Petrol şirketlerinin finans ve banka işlemleri ise Rusya'nın Volga bölgesinde olan Samara şehrinde gerçekleştirilmekteydi ${ }^{66}$. 1914 raporları, Batı Kazakistan üzerinden gerçekleştirilen ve gittikçe yoğunlaşan petrol taşımacıllğında büyük rolün Aktöbe eyaletine düştüğünü göstermektedir ${ }^{67}$.

Kazak bozkırlarında ilk başta Rus (Kazak) askerleri tarafindan açık kuyulardan alınan petrol henüz satışı çok sınırlı olduğu için küçük miktarlarda çkarılmaktaydı. Petrol üretiminden ylllk gelir elde etmek isteyen Guryev askeri yönetimi bu işi kontrolüne almaya çalıştı. 1911'de Dossor'da Rus işşileri geniş bir petrol alanını keşfettiler. Keşfi yapanlar arasında Bakü, Çeleken ve diğer bölgelerde petrol alanında çalışma deneyimi olan Ermeniler de bulunmaktaydı. Ocak 1913'te Samson Apresov adındaki bir Ermeni ${ }^{68}$, yılda 12 bin ruble maaşla Dossor petrol alanının yöneticisi olarak çalıştı ${ }^{69}$. Apresov, 1912'de Emba bölgesindeki Makat'ta ilk petrol arama çalışmalarını başlattı. Makat sahasının Emba-Hazar petrol ve gaz şirketinin usta ve işşilerinin Ocak 1914 tarihli karnesinde geçici işçi olarak çalışan Ermenilerin isimleri kayıt edilmiştir. Bunlar arasında Khaçatur Grigoryan, Sarkis Naraslyants, Arşak Jamgarov, Arşak Ayrapetov, Saak Melkumov, Nikolai Khurşudov, Avetis Abramyants, Vardan Dadoyants, Vladimir Buniyatov,

Finlandya'ya kaçtı ve 11 Kasım 1922'de Fransa'daki Mason locasına üye oldu. Geniş bilgi için bk. I. L. Babich, Severokavkazkaya Natsia v Evropeiskoi Migratsii: Mif ili Real'nost, Sankt-Peterburg 2012; Russkiye Birjevoye Novosti, 1915: 282.

66 KCMDA, Fon No. 450, Kayit No. 1, Dosya No. 1, s. 1-66.

67 KCMDA, Fon No. 450, Kayıt No. 1, Dosya No. 2, s. 1-9.

6811 Kasım 1874 Şuşa şehrinde bir demirci ailesinde doğdu. 1893’te Şuşa Okulu'ndan mezun oldu. Aynı yıl St.Petersburg Madencilik Enstitüsü'nü kazandı ve 1900 yılında madencilik (cevher) bölümünden mezun oldu. S.M. Apresov'un diğer faaliyetleri, iki yıl boyunca jeoloğu ve yöneticisi olduğu "EmbaHazar Petrol Ortaklı̆̆ı" girişiminin "Ural-Embenskiy" bölgesinde gerçekleşti. Bolşevikler iktidara geldikten sonra, bölgede komünist sisteminin yerleşmesinde büyük rol oynadı. 1939'da profesör oldu ve 1952'ye kadar Sovyet Jeoloji Araştırması Genel Müdürlüğ̈nü yürüttü. Bakü ve Kazakistan'daki petrol sanayisinin gelişmesiyle ilgili çok sayıda ilmi çalışması yayımlandı. 1964'e kadar M. Azizbekov Azerbaycan Endüstri Enstitüsü’nde Genel Jeoloji Bölüm Başkanlığını yürüttü.

69 A. A. Fursenko, Neftyanye Trestr i Mirovaya Politika 1880-1918 Gody, Moskva 1965. s. 7-12.

Belleten, Nisan 2021, Gilt: 85/Say1: 302; 227-277 
Enok Guliyants ve diğerleri. 18 kişiden daha fazla Ermeni petrol şirketlerinde önemli konumlarda görev yapmaktaydı ${ }^{70}$. 24 Haziran 1915'te Z.A.Agamov ve G.A.Kasparov adlı Ermeniler, Emba-Hazar petrol-sanayi şirketinin hissedarları arasinda bulunmaktaydi ${ }^{71}$.

Bu şirketlerin 1901 ile 1916 yılları arasındaki nakit ödemelerinde yer alan maaş listesine bakıldığında çalışanların \%71’i Ermeni, \%12'si Rus, kalanlarının da yerli Kırgızlar (Kazaklar) olduğu ortaya çıkmaktadır ${ }^{72}$. Buna karşı Embî petrol sahalarında hizmet veren çalışan ve işçilerin personel defterlerine bakıldığında Rus ve Ermeni görevlilerin 90 ruble 40 kopek ile 156 ruble arasında maaş aldıkları görülmektedir ${ }^{73}$. Ağırlıklı olarak ağır işlerde çalışan Kazaklar arasında bulunan Kökköz Begimov ve Utebai Baimaganbetov bir ayda sadece 5 rublenin biraz üstünde bir maaşla çalıştı ${ }^{74}$. Arşiv belgelerindeki diğer bazı kayıtlarda da Vasiliy Avernyan ve Porfiriy Malınyan isimli Ermeni işçilerin ücretleri yerel işçilerin ücretlerinden fazla idi. Kırgızlar (Kazaklar) 36 ruble 45 kopek, Ermeni işçiler ise 89 ruble 9 kopek maaş alıyordu ${ }^{75}$.

Emba-Hazar Petrol-Sanayi Şirketi yönetim kurulunun muhtırasında: "Siparişi değerlendirirken maalesef, Petrograd'daki şirketlerin hepsinin karar alamayacă̆ sonucuna vardım, çünkü Bakü'de (Nobel kardeşler) ve başka bazı isimler (Ermeniler) buna engel olmaktadır ve tüm işlemleri ellerinde tutmaktadrr" denilmektedir ${ }^{76}$. Bu ifade o dönemde petrol üretimi alanında hizmet veren hemen hemen tüm firmaların tekelleşme temayülünde olduklarını gösteren önemli bir işarettir. Alanda hizmet gören münferit kuruluşların petrol sahalarındaki çalışmalarına dair kaleme alınan 01 Mart 1913 tarihli rapora göre, Dossor, Iskine, Makat ve Emba-Hazar petrol sahalarından 10 günde 177 yeni petrol kuyusu açıldığını görmekteyiz ${ }^{77}$. Bu sayı

70 KCMDA, Fon No. 679, Kayıt No. 1, Dosya No. 172, s. 1-15. Makat sahasında petrol üretimi ile ilgili günlük raporlar.

71 KCMDA, Fon No. 679, Kayıt No. 1, Dosya No. 163, s. 1-29. Batı Kazakistan'ın Petrol Şirketin yönetim kurulu ile sondaj, finansman, ekipman yazışmaları.

72 KCMDA, Fon No. 681, Kayit No. 1, Dosya No. 4, s. 1-17. Emba Petrol şirketinin polis, yol ve tıbbi bakımın Ural-Hazar Petrol Derneği ile anlaşması.

73 KCMDA, Fon No. 680, Kayit No. 1, Dosya No. 5, s. 4-7.

74 KGMDA, Fon No. 680, Kayıt No. 1, Dosya No. 4, s. 4-5.

75 KCMDA, Fon No. 680, Kayit No. 1, Dosya No. 14, s. 30-31.

76 KGMDA, Fon No. 681, Kayıt No. 1, Dosya No. 16, s. 17-19.

77 KCMDA, Fon No. 681, Kayıt No. 1, Dosya No. 3, s. 69. 
I. Dünya Savaşı öncesinde Batı Kazakistan'ın petrol sahalarındaki yoğun çalışma hızını ve gelişmeyi göstermektedir. Bu bağlamda Makat sahasında petrol üretimi ile ilgili günlük raporlara göre Emba-Hazar petrol ve gaz kompleksinden günde 200 ile $300 \mathrm{Pud}^{78}$ petrol üretilmekteydi ${ }^{79}$.

Yukarıda verilen bilgiler çerçevesinde, Çarlık yönetiminin Türkistan'ı işgal etmesiyle birlikte Kafkas bölgesinden hareketlenerek Rus işgaline paralel biçimde Türkistan'a gelen Ermenilerin, bölgede zanaata dair işlerde hakim duruma gelmeye başladıkları, tüccarlık yaptıkları, dükkânlar açtıkları ve kendilerine ait yerleşim birimleri oluşturdukları anlaşılmaktadır. Ermeni tüccarlar Rusya ile mal alışverişinde bulunmakta, zengin Ermenilerin birçoğu pamuk temizleme, petrol şirketleri, deri ve diğer işletmeleri ellerinde tutmaktaydılar ${ }^{80}$. 1917'ye doğru, Bolşevik İhtilali'nin hemen öncesinde Türkistan'daki Ermenilerin sayısı belirgin bir şekilde artmıştı.

Yukarıda Çarlık döneminde Türkistan coğrafyasında iskân edilen Ermenilerin bölgedeki faaliyetlerinden bahsedildi. Rus arşiv kaynaklarına göre genel olarak Ermenilerin Türkistan'da Rus hâkimiyetinin güçlenmesinde ve yerleşmesinde büyük rol oynadıkları anlaşılmaktadır. Bu çerçevede Çarlık yönetiminin Ermenileri kendi stratejik hedefleri doğrultusunda bölgeye yerleştirdiği ve avantajlı bir konuma getirdiği anlaşılmaktadır.

\section{Bolşevik İhtilali ve Türkistan Muhtariyetine Karşı Taşnak Ermenilerin Kullanılması}

1917’ye kadar merkezi Taşkent olan Türkistan bölgesinde Sovyet yönetimi Petrograd'taki Bolşevik İhtilali'nden çok kısa bir süre sonra başladı. 28 Ekim 1917'de Türkistan Bölgesi Halk Komiserleri Konseyi, Geçici Hükümetin bölge temsilcileri konseyini feshetti.

15-22 Kasım 1917 tarihleri arasında Taşkent’te III. Mahallî İşçi, Asker ve Köylü Temsilcileri Kongresi düzenlendi. Kongrenin ele aldığı önemli ve acil konulardan biri mahallî Bolşevik makamların örgütlenmesi oldu. Tartışma sırasında kongre delegeleri iki ana gruba ayrıldı. Birleşik Sosyal Demokratlar tarafindan aday

78 Pud, Rus ölçü sisteminin kütlesinin eski bir ölçü birimidir. 1899 yılının verilerine göre bir Pud 16.3804964 kg'a eşittir.

79 KCMDA, Fon No. 679, Kayıt No. 1, Dosya No. 129, s. 1-45.

80 I. A. Amiryants - A.A. Grigoryants, Armyane v Sredney Azii. Sovremennoye Razvitiye Etniçeskih Grupp Sredney Azii I Kazahstana, Çast 1., Moskva 1992, s. 157-171. 
gösterilen ilk grup, yeni kurulan hükümete işçi ve köylü delegeleri, şehir yetkilileri ile Müslümanların girmesi gerektiğini öne sürdü. Aynı zamanda, Bolşevikler ve Sosyalist-Devrimci-Maksimalistleri içeren ikinci grup, bölgesel gücün Rusya'daki Sovyet hükümeti örneği üzerine inşa edilmesi gerektiğini iddia etmekteydi. Nihayetinde Kongre, Türkistan'ın, Müslüman Türkler ve Geçici Hükümet temsilcileri olmadan Bolşevikler ve sol sosyalist devrimcilerden oluşan Halk Komiserleri Konseyi tarafindan yönetilmesi gerektiği sonucuna vardı. Böylelikle, Halk Komiserleri Konseyi, Türkistan bölgesinin yeni anayasal yönetim organı olarak yapılandırıldı. Halk Komiserleri Konseyi oluşturulurken, yerel TürkMüslüman nüfus temsilcilerinin idarecilik pozisyonlarına dahil edilmemesine de karar verildi. Kongre, bu kararın "Müslïman halkmn askerler, iş̧̧iler ve köglï milletvekilleri üzerindeki gücünün yerel bir anlaysşnn olmamass ile onlarm arasinda proletaryann sinf örgütlerinin bulunmaması nedeniyle, en yüksek bölgesel devrimci otoritelere katılım ile

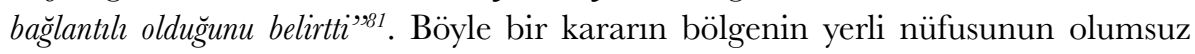
tepkilerine yol açabileceğini anlayan Kongre: "Yerli nüfusun büyük çoğunluğu aktif istihdamdan uzaklaştırlmayacaktı, çünkü her insanın hayatı dikkate alınır ve onlara komiserler görevlendirilir" kararını aldı. Kongre'nin kararına göre, komiserler bölgedeki düzeni sağlayacak, yerel nüfusun davranış ve kültürel hayatını araştıracak, Bolşevik idaresini bilgilendirecek ve milli ayaklanmaları zamanında bastıracakt ${ }^{82}$.

Kongrede, Türkistan müslümanlarının bağımsızlı ve muhtariyet ile ilgili görüşlerini Kasım 1917 ve Şubat 1918 tarihleri arasında Umum Rusya Merkezi Yönetim Komitesi üyesi ve Orta Asya ile Batı Sibirya RSFSR Halk Komiserliği, ardından Türkistan Merkezi Yönetim Komitesinin başkanlığını yapan P. A. Kobozev $^{83}$ şu şekilde ortaya koymaktaydı: "Rus ve Müslüman kardeşlerimiz arasında

81 RF SSTA (Rusya Federasyonu Sosyal-Siyasi Tarih Arşivi), Fon No. 71, Kayıt No. 34, Dosya No. 1632 , s. 9-12.

82 RF SSTA, Fon No. 71, Kaylt No. 34, Dosya No. 1632: s. 9-12.

83 Pyotr Alekseeviç Kobozev 26 Ağustos 1878'de Rusya'nın Ryazan bölgesi Pesoçnıy köyünde köylü bir ailenin çocuğu olarak dünyaya geldi. Önce bir ilahiyat okulunda, daha sonra Moskova İlahiyat Semineri'nde eğitim gördü. Bu dönemde sosyal demokrat çevreye katıldı. 1899'da devrimci hareket içinde bulunduğu gerekçesiyle tutuklandı ve Riga şehrine sürgüne gönderildi. Burada 1900-1904 yılları arasında Politeknik Enstitüsü'nde eğitim aldı. 1918'de P. A. Kobozev Lenin'den iç savaş koşullarında oldukça zor bir görev emri aldı: Taşkent’ten Bakü'ye giderek Bakü'deki Bolşeviklerle petrol sahalarının millileştirilmesi sorununu tartışmak ve daha sonra Türkistan üzerinden Rusya'nın merkezine petrol dağıtımını sağlamak. Komunist Partisi Merkez Komitesi Marksizm-Leninizm Enstitüsü fonlarında P. A. Kobozev'in anıları kayıt edilmiştir. Bu anılara göre Kobozev, Türkistan'da Bolşevik sisteminin oluşumunda "Basmacı" hareketine karşı büyük katliamlar düzenlemiş ve Taşnakçı Ermeni askeri birliklerinin kuruluşunda mühim bir rol oynamıştır. İç savaşın sonunda, Pyotr Alekseeviç 
bir çatışma istemiyoruz, ilk ve son sözümüzü söylüyoruz: Milli işlerimize ve kaderimize müdahale etmeyin (Bolseviklerin)... Sizler (Türkistan halkı) kendinizi gerçekten ne kadar

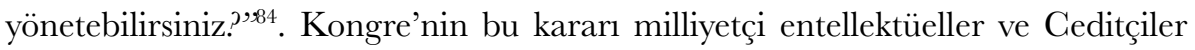
tarafindan kabul edilmedi. Böylece Türkistan'da çifte "hükümet” (yönetim) ortaya çıkt1.

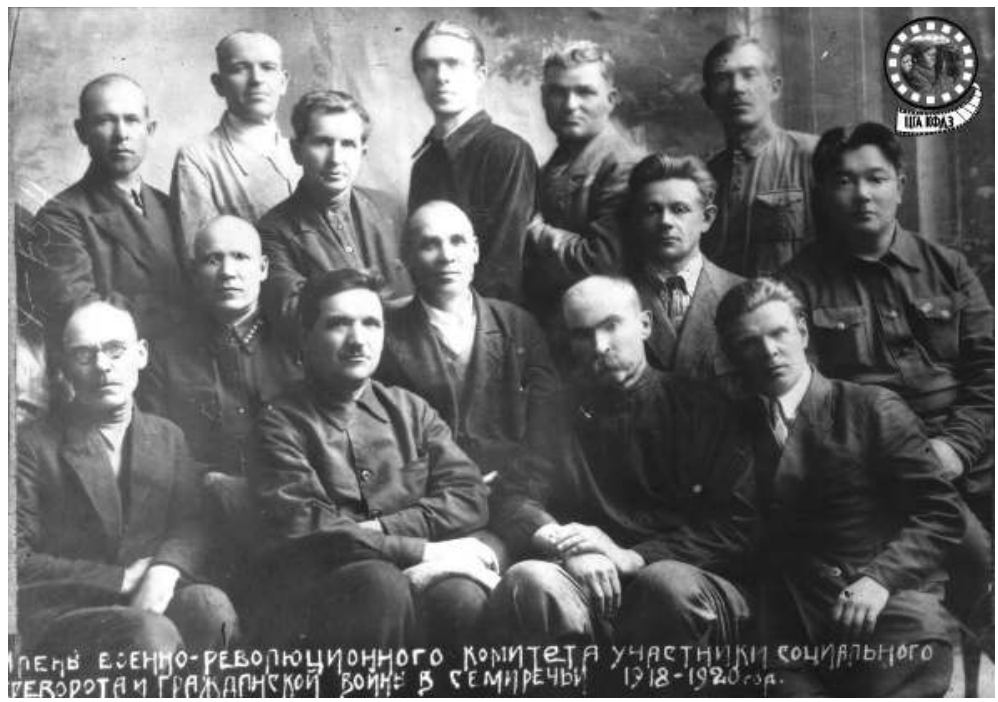

Resim 2: Semireçi'de (Yedisu) Sosyal Devrim ve İç savaşa Katılan Askeri Devrimci Komite Üyeleri 1918-1920 85

Türk liderler, yaptıkları bir çok milli kongre ve Müslüman kamu teşkilatı toplantılarında yeni Bolşevik hükümetinin tanınmayacağını duyurdu. Böylelikle Türkistan'da milli kimlik inşası çabası ve istiklâl hareketi ortaya çıktı. 1917 yılında Türkistan'da Türklerin bağımsızlı̆̆ı gayesini güden Basmacı hareketi doğdu ve 1937 yılına kadar varlığını sürdürdü. Bolşevik iktidarı "proletaryanın diktatörlüğü"

ağır bir hastalığa yakalandı. Parti Merkez Komitesi 1 Eylül 1922'de P. A. Kobozev'in Uzak Doğu Cumhuriyetinin Başkanı olarak atanmasına ilişkin kararı kabul etti. Anılara göre Lenin şöyle demişti: "Pyotr Alekseeviç, sizden büyük bir talebimiz var ... hastalığınıza rağmen, sizden bir kez daha partiye yardım etmenizi istiyoruz. Uzak Doğu'dan müdahalecileri kovup Sovyet iktidarını orada kurmanızı istemekteyiz". Geniş bilgi için bk. B. N. Çistov - M. A. Zhohov, Poslanets Partii: Oçerk Voyenno-Politiçeskoy Deyatelnosti P.A.Kobozeva na Vostoçnom Fronte (1918-1919), Voyenizdat, Moskva 1980, s. 158.

84 RF SSTA, Fon No. 133, Kayit No. 1, Dosya No. 24, s. 5-8.

85 KC MDFFBSKA, Arx. 2-34451, 2-36213.

Belleten, Nisan 2021, Cilt: 85/Sayı: 302; 227-277 
sloganı ile kızıl orduya dayanarak, bölgede demokrasi yoluyla milli yönetimi kurmak isteyen Türkistan Muhtariyet hareketini ise Sovyet düşmanlığ ile suçlayarak ortadan kaldırdı. ${ }^{86}$

Türkistan Bolşevikleri, Eylül 1917'de Petrograd'dan daha önce Taşkent merkezinde iktidarı ele geçirdiler ve akabinde yerli Türk-Müslüman nüfusun kendi topraklarının yönetimine katılmasına karşı çıktılar. Türk-Müslüman halklarının bağımsızlığını kabul etmek istemeyen Bolşevikler kendilerine yeni müttefikler aramaya başladı. Bölgedeki kontrolü tam olarak sağlayamayacağını bilen Bolşevik hükümeti, bu aşamada Taşnak Ermenilerle ittifak kurdu.

Taşnakçı Ermenilerin 1917'de Fergana vadisindeki katliamlar ile köylere yaptığı saldırılar Bolşeviklere büyük imkânlar yarattı. Bu dönemde "Tüm dükkân sahipleri, sarap tïccarlan, kuaförler, kasaplar ve diğer Ermeniler" birdenbire "devrimci" oldular ve şehirlerde Bolşevik iktidarını kurmak için Kızıl Orduya katıldılar ${ }^{87}$.

Ocak 1918'de Taşkent'teki Türkistan Muhtar yönetimi, Sovyet iktidarını kabul etmesi konusunda bir ültimatom aldı. Buna karşlık Türkistan Milli Kurtuluş Hareketi Bolşevik yönetimini kabul etmeyeceğini ilan etti. Muhtariyeti ilan eden Türkistan Milli hareketini yok etmek amacıyla K. P. Osipov ${ }^{88}$ başkanlığında 11 asker ve topçu treni Moskova'dan Taşkent'e geldi. Kızıl asker "cezalandincular" arasında Taşnakçı Ermeni birliklerinin sayısı 7 vagondu $^{89}$. Bu Ermeni birlikleri 1918'den 1922'ye kadar devam eden yıllarda Türkistan Türklüğüne karşı açık bir katliam ve zulüm politikası yürüttüler. 1918'in başından itibaren Türkistan'ın pek çok bölgesinde, Bolşevik birliklerinin çoğu Taşnakçı Ermenilerin yönetimindeydi.

86 Kılınçkaya - Omarbekov - Egamberdiev, agm., s. 16.

87 Turar Ryskulov, Revolutsiya i Korennoye Naseleniye Turkestana, Taşkent 1925, s.105-107; Ali Bademci, Kendi Arşiz Belgelerine Göre 1917-1934 Türkistan Milli İstiklal Hareketi Basmacılar (Korbaşılar), Kamer Yayınları, 3. Bask1, İstanbul 2019, s. 203, 212.

88 Konstantin Pavloviç Osipov 1896'da Rusya'nın Krasnoyarsk şehrinde doğdu, Rusya tarihinde devrimci maceraperestliğin en parlak temsilcisi olarak bilinir. Daha sonra Türkistan'daki askeri karargâhta görev aldı. Türkistan Halk Komiserleri Konseyi başkanı F. I. Kolesov ile arkadaş oldu ve o dönemin meşhur Bolşevik simalarıyla tanıştı ki; bunların arasında P. A. Kobozev de vardı. Osipov Türkistan'da Taşnakçı Ermeni askerî birliklerin kurucusu olarak bilinmekte ve 1919'da Taşkent ahalisini katleden bir Bolşevik olarak tanınmaktaydı. Türkistan'da Bolşevik iktidarının kurulmasıyla beraber Osipov daha sonra bu defa Bolşeviklere saldırılar organize etmiştir. En büyük saldırılardan biri Ocak 1919'da Taşkent'te düzenlendi. Osipov Taşnakçı Ermenilerle birlikte Menşeviklerle birleşerek Türkistan'da kendi devletini kurmaya çalışmıştır. Ancak Bolşevik Kızıl Ordu birliklerinin savaş açmasıyla 1919'da tutuklandı ve idam edildi. Geniş bilgi için bk. S. Agzamkhodzhayev, Istoriya Turkestanskoy Avtonomii, Taşkent 2005.

RF SSTA, Fon No. 71, Kayit No. 34, Dosya No. 1503, s. 15-17. 
Bu yıllarda Türkistan'daki büyük ekonomik kriz ve kıtlk sonucunda, Kızıl Ordu'ya mensup Taşnak Ermeni birlikleri, Bolşevikler lehine iktidarı ele geçirmek bahanesiyle köylere saldırdı ve Türk-Müslüman ahaliye ağır eziyetler yaptı. Türkistan'da kurulan Bolşevik sistemi, Taşnak Ermenilerin Türk-Müslüman halklarının mallarını son lokmasına kadar yağmalamasına neden oldu. Türkistan ekonomisindeki kriz doğrudan şiddete yol açtt. Türk-Müslüman nüfus yoksullaşt, Taşnakçı Ermeniler ev eşyalarına bile el koydu. Kızıl Ordu'nun ihtiyaçları gerekçe gösterilerek yerli halkın atlarına el konuldu ve bunların birçoğu Taşnakçı Ermenilere verildi. Daha sonra Kızıl Ordu'ya mensup Ermeniler kendilerine dağıtılmış olan silah ve mühimmatları para karşılığında Basmacılara sattılar ${ }^{90}$.

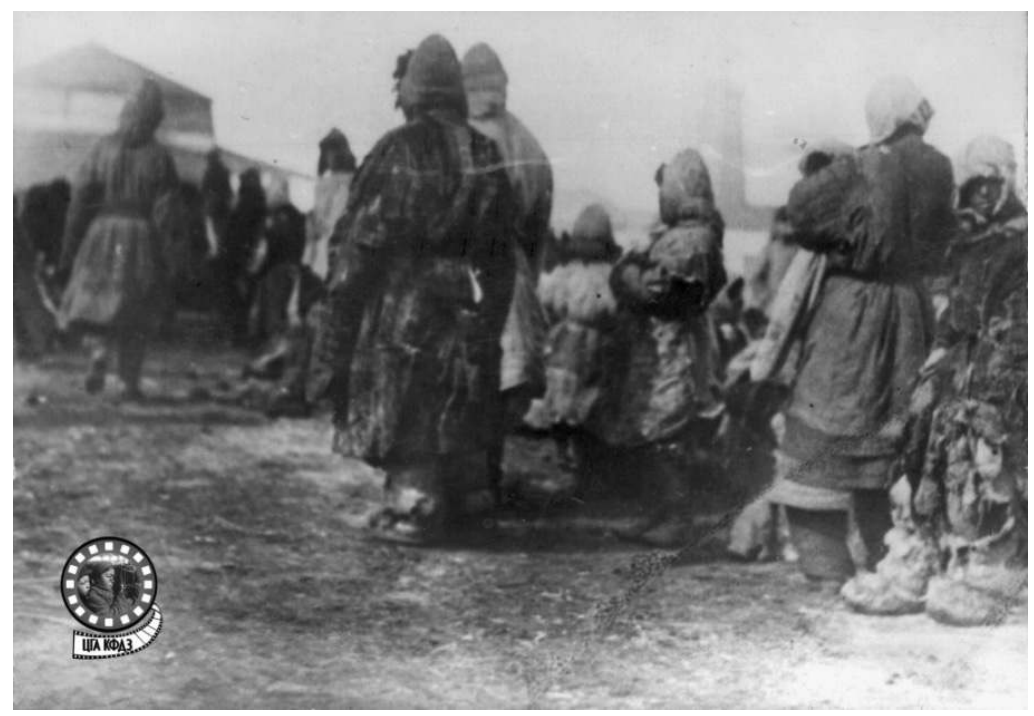

Resim 3: Taşnak Ermenilerin Saldırılarından Sonra 1925 Yılında Kazak Pazarlarındaki Fakirler. Pavlodar ${ }^{91}$.

Türkistan Türklüğü-Müslüman halklara karşı yapılan benzer soykırım politikası, Güney Kafkasya'da da yapıldı. Bakü Bolşevikleriyle birleşen Taşnakçı Ermeniler, Azerbaycan Türklerine ve onları temsil eden "Müsavat Partisi"ne karşı saldırılar organize ettiler. Mart-Nisan 1918'de Bakü Bolşevik müfrezesinin 6.000 askeri ve

90 RDAA (Rusya Devlet Askeri Arşivi), Fon No. 25896, Kayıt No. 1, Dosya No. 2, s. 63-68.

91 KC MDFFBSKA (Kazakistan Cumhuriyeti Merkezi Devlet Film ve Fotoğraf Belgeleri ile Ses Kayıtları Arşivi) Arx. 5-3448. 
4.000 silahlı Taşnak Ermeni bölgedeki Türkleri katletti. Bakü Sovyeti Konseyi Başkanı, Bolşevik-Taşnak S. G. Şaumyan 15 Mart 1917 tarihinde Bakü Sovyeti toplantısında yaptığı konuşmada, Azerbaycan'da yapılacak katliamın işaretlerini verdikten kısa bir süre sonra bölgede çatışmalar başladı. Bolşevik I. Suhartsev, 13 Nisan 1918' de Bakü Sovyeti toplantısında sayıları 7.000 bini bulan Taşnak Ermeninin Kızıl Ordu ile birlikte Bakü'de yaptıkları korkunç katliamdan sonra konu ile yaptığı konuşmada: “ $\ddot{U}_{c}$ gün zarfinda Bakü'de şiddetli çatışmalar boy gösterdi, bir tarafta Ermeni milli birlikleriyle beraber dövüssen Kizıl Ordu, diğer tarafta Müsavat Partisinnin idaresindeki Müslüman kuvvetler vardl. Sonuç bizim açımızdan güzel oldu. Düssman tamamen imha edildi" demekteydi ${ }^{92}$. Bu ortamda bir haftada neredeyse önde gelen Türkçü ve Sovyet karşıtları katledildi"3 . Bunu doğrulayan Şaumyan da: "Yaklaşık 6.000 kişiden oluşan silahlı kuvvetlerimiz vard, Daşnaktsutyun'un 3-4 bin askeri bizim tarafimızdan yönetildi. Ikincisinin (Taşnakçı Ermenilerin) katılım iç savaşın bir kısmını kaçımılamayan milli bir katliam haline getirdi. Kasten yaptık. En çok zaran Müslüman yoksullar çekti... Verilere göre yaklaşık 20.000 Azeri Müslüman öldürüldü” demekteydi ${ }^{94}$. Taşnak Ermeniler, Bakü ve diğer şehirlerdeki Türk nüfusunu yok ederek bölgedeki petrole el koyarak burayı bir Ermeni toprakı haline getirmeye çalışıyorlardı ${ }^{95}$. Mart 1918 olaylarına iştirak eden ve daha sonra Ermenistan Bolşevik Partisi Sekreteri olan Levon Mirzoyan: "Gerçekten Sovyet hakimiyeti Taşnaklan kendi amaçlan doğrultusunda kullanmıştı»" demekteydi ${ }^{96}$.

Azerbaycan örneğinde açıkça görüldüğü gibi Taşnak Ermenilerın Türkistan'daki faaliyetlerindeki "Türk düşmanlığı" politikaları açıktır. 1918 yılı başında, 60'ı Taşnakçı Ermenilerden olan 150 kişilik devrimci Kızıl Ordu birliği, Hokand'daki Bolşevik liderliğinde görevli olan Ermeni O. A. Saakov ${ }^{97}$ başkanlı̆̆ında, makineli tüfek ve toplarla silahlandırılarak "Basmacı" Milli Mücadelesi’nin lideri Ergeş’in

92 Beşir Mustafayev, "Kafkaslarda Müslüman-Türk Soykırımı (1905-1920)", Türk Dünyası Incelemeleri Dergisi, XII/ 1 (Yaz 2012), s. 533-561, s. 541 vd.

93 Nadir Devlet, Rusya Türklerinin Milli Mücadele Tarihi (1905-1917), Türk Tarih Kurumu, 3. Bask1, Ankara 2020, s.169.

94 S. G., Şaumyan, Pisma 1896-1918, Erevan 1952, s. 62-66.

95 Mustafayev, agm., s. 542 vd.

96 I. V. Niftaliyav, "Azerbaydjanskaya Diplomatiçeskaya Missiya v Armenii Posle Aprelskoy Okupatsii 1920 g." İstoriya i Yeyo Problemi, No.1, 2006, s. 74-78.

97 Onik Arzumoviç Saakov, 1905-1907 devriminin Transkafkasya ve Ekim Devrimi’nde, Türkistan'da gerçekleşen iç savaşlara aktif olarak katıldı, 1918-1919 Hokand Konseyi Başkanı, daha sonra Türkistan Komünist Partisi Hokand Şehir Komitesi Başkanı olarak Basmacılara karşı savaşlarda yer aldı. Taşnakçı Ermenilerin askeri birliklerini yönetti ve Hokand bölgesindeki Türk katliamında büyük rol üstlendi. 1937'de Stalin'in kararı ile tutuklandı, 1955'de aklandı. Geniş bilgi için bk. Reforma v Krasnoy Armï. Dokumentr i Materiah 1923-1928, Kniga 2, Moskva 2006. 
köyünü tamamen yaktı ${ }^{98}$. Askeri Konseyin Türkistan İkinci Tüfekli askeri birliklerinin 358 nolu emri gereğince Basmacı hareketine katılan bütün TürkMüslümanların idam edilmesi emri verildi. Bu belgede, "Basmacılar iş̧̧ilerin düşman saylhrve infaz edilir... Basmacılarla iliski kuran veya yardmda bulunan her kimse, savaş zaman yasalarn uyarnca en ağgr cezalara maruz kalacaklardır... Sovyet iktidarnı kışkrtan ve askeri görevlerimizin uygulanmasm engelleyen, karş-devrimci sahte söylentiler yayan tüm provokatörler yeryüzünden silinecekler" gibi hükümler yer almaktadır ${ }^{99}$. Arşiv belgeleri Taşnak Ermenilerin Bolşevikler tarafından kullanıldığını açık bir şekilde kanıtlamaktadır.

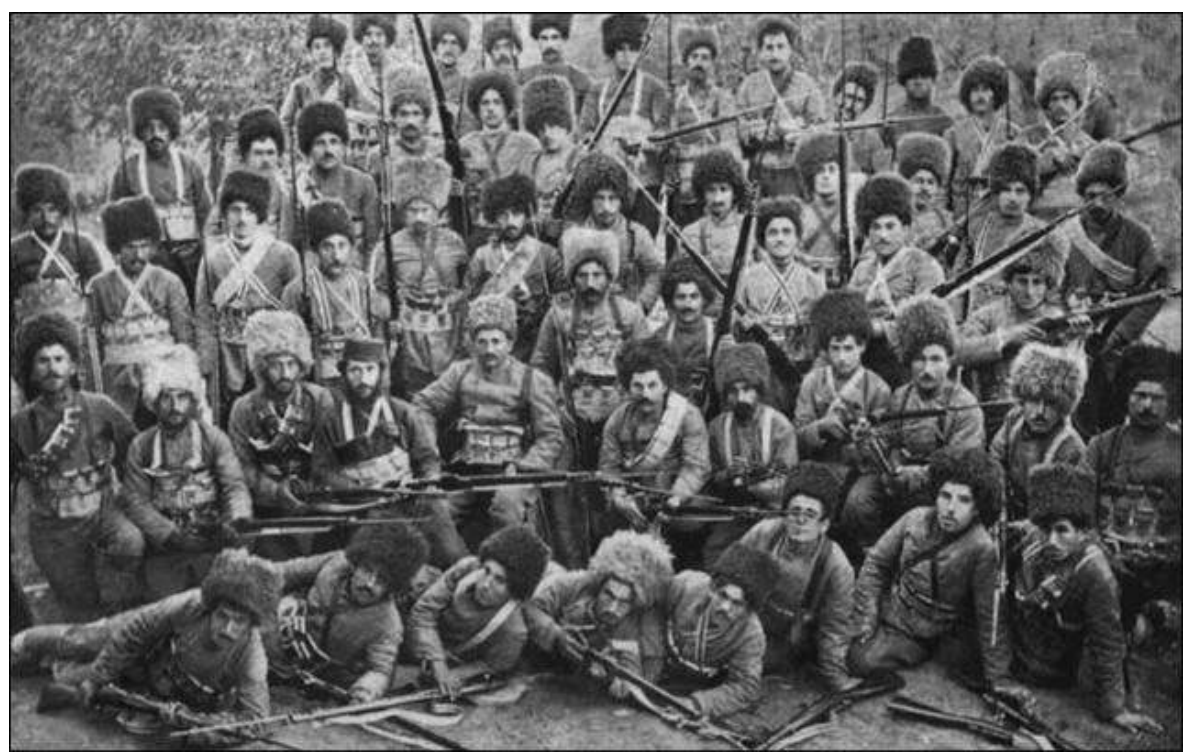

Resim 4: Bolşevik Kızıl Ordu ile Birleşen Taşnak Ermeni Askeri Birlikleri'100

Taşnakçı Ermenilerin Türkistan'daki ve özellikle Fergana Vadisi'nde yaptıkları soykırım, Türkistan Muhtariyeti’nden (Hokand Hükümeti) sonra Bolşevikler tarafindan kurulan Türkistan Otonom Sovyet Sosyalist Cumhuriyeti'nin Sekreteri

98 M. Buttino, Revolutsiya Naoborot. Srednaya Aziya Mejdu Padeniyem Tsarksoy Imperii i Obrazovaniyem SSSR, Moskva 2007, s. 63.

99 RF SOMDA (Rusya Federasyonu Sovyet Ordusu Merkez Devlet Arşivi), Fon No. 110, Kayıt No. 1, Dosya No. 71, s. 19-21.

100 A. Lalayan, "Kontrrevolyutsionnıy "Daşnaktsutün” i İmperialistiçeskaya Voyna 1914-1918 Godı". Revolyutşsonny Vostok, No. 2-3 (36-37), Moskva 1936, s. 76-99.

Belleten, Nisan 2021, Cilt: 85/Sayı: 302; 227-277 
Turar Rıskulov'un dönemin olaylarını anlattığı eserinde Bolşeviklerin Basmacı hareketini boğmak için Taşnak Ermenileri kullandığını ortaya koymaktadır. 1925 'te Taşkent'te yayınlanan İhtilal ve Türkistan'ın Yerli Halkı eserinin "Ferganada Taşnakçılar Neler Yaptı" başlıklı bölümünde, "Ayaklanmann bastrrlmasinn en sıcak anlarnda, dokuz gün boyunca Hokand'da çeşitli soygunlar yapıldı. Firsaţ̧ı Taşnaklar derhal "para" kazanmaya karar verdiler ve şehirde kapsaml bir "tasfye" yaşande" şeklinde yazmaktadır. Haziran 1918'de Taşnakçı Ermeniler, Oş şehrini (şimdiki Kırgızistan) kuşattı ve aynı yılın Aralık ayında Fergana Vadisi'nin kuzeyindeki Celal-Abad bölgesine saldırdılar. Aralık 1918'de bir grup Taşnakçı Ermeni, bölgedeki tüm Müslüman kadınları zorla kaçırdı ve onları Andican kalesine ganimet olarak getirdi ${ }^{101}$. Bu durum dönemin tanıklarından Zeki Velidi Togan'ın eserinde de açı bir şekilde belirtilmektedir. Hatta Bolşeviklerin eline geçen Türkmenistan ve diğer bölgelerde Ermenilerin yeniden istihdam edildikleri anlaşılmaktadır ${ }^{102}$.

Hokand'ın eski semtlerinde bulunan Taşnakçı Ermeniler Şubat 1919'da bölgedeki Türkleri Andican'da organize edilen saldırılarla suçlayarak harekete geçtiler. Hafta boyunca Ermeniler tarafindan Türklerin evlerinde yağma, cinayet ve tecavüzler yapıldı ve Fergana'da çok sayıda Türk katledildi ${ }^{103}$.

Türkistan'da Sovyet iktidarını kurmak ve kalııı olarak şekillendirmek için bölgesel askeri cepheler veya devrimci askeri cepheler kullanıldı. Bu cephelerde Ermeni birlikler aktif durumda idiler. Türkistan'mn Yedisu Kuzey Cephesi, Semipalatinsk'ten Sergiopol, Lepsinsk'e giden Kazakistan’ın kuzey bölgelerini “özgürleştiren” 22 Temmuz 1918 tarihli İcra Komitesi kararı ile Kızıl Ordu talimatlarına göre Taşnak Ermeni birlikleri Yedisu cephesine dâhil edildi. Bu askeri birliklere Yedisu ve Batı Kazakistan'a iskân edilen Ermenilerle birlikte Kafkasya'da oluşturulan 11 Taşnak Ermeni askeri birliği de dahil edildi ${ }^{104}$. Birinci Semireçinsk (Yedisu) Bölge Kongresi'nin 08 Kasım 1918 tarihli kararı ile Cephenin Askeri-Siyasi Karargâhı oluşturuldu ve 10 Şubat 1919'da yerine operasyonel ve siyasi bölümler konuldu. 6 Haziran 1919'da Semireçinsk Kuzey Cephesi delegelerinin Dördüncü Kongresi kararına uygun olarak, 8 Haziran 1919 tarih ve 16 nolu talimatı ile ön

101 Turar Rıskulov, Revolyutsiya i Korennoye Naseleniye Turkestana, Taşkent 1925, s. 107.

102 Ahmet Zeki Velidi Togan, Bugünkü Türkili (Türkistan) ve yakn Tarihi, Batr ve Kuzey Türkistan, C I, 2. Bask1 İstanbul 1981, s. 382, 389.

103 RDATA (Rusya Devlet Askeri Tarih Arşivi), Fon No. 149, Kayıt No. 1, Dosya No. 198, s. 1-3

104 RDATA, Fon No. 131, Kayıt No. 1, Dosya No. 17, s. 14

Belleten, Nisan 2021, Cilt: 85/Say1: 302; 227-277 
birliklerin emriyle, komutan, siyasi ve askeri-siyasi komiserlerin katıldığ Askeri Konsey oluşturuldu. Devrimci Askeri Konsey, operasyon bölümünün tüm yetkilerini kendi üzerine ald ${ }^{105}$. Böylelikle bölgedeki Bolşevikler Ermenilerle birleşerek Komünist sistemi kurmaya yönelik bütün tedbirleri almış oldular. Yani Türkistan'da Bolşevik birliklerine dâhil edilen Taşnak Ermeni birlikleri iki taraftan askeri operasyonlar gerçekleştirdi.

Kızıl Ordu Basmacıları ortadan kaldırmak için son derece kanlı saldırılar düzenliyordu. Nitekim 22 Eylül 1919 ve 26 Eylül 1919 tarihlerinde Andican şehri civarlarında Basmacılar ve Kızıl Ordu arasında gerçekleşen çarpışmalar vuku buldu. Bu çarpışmalarda Ermeni Taşnak birlikleri de bulunmaktaydı ${ }^{106}$. 1919'da 170 silahlı Taşnak Ermeni askeri Hokand'a saldırdı ancak oradaki Türkler bu saldırıya karşı direndi. Direnişten dolayı Taşnaklar Hokand'ı yaktı ve yerli halkın büyük kısmını öldürdü. Başka bir Taşnak Ermeni grubu Güney Kazakistan'daki Sozak yerleşimini ele geçirdi ve burada da tüm sakinleri öldürdü ${ }^{107}$. Aynı şekilde Taşnak Ermeniler, Kuzey Kazakistan'ın Pavlodar bölgesinde de yerli halkı katletti. Kızıl Ordu’nun Üçüncü Ermeni birimleri, Bazar-Kurgan yakınlarındaki Türk-Müslüman ahaliye saldırdı. 20 gün içinde, yaşına bakılmaksızın tüm TürkMüslümanların öldürüldüğ̈̈ ortaya çıktı. Ayrıca bölgedeki her köye saldırıldı, hayatta kalanlar çekilmeye mecbur kaldı. Ancak Ermeniler geri dönerek, toprağa verilenlerin mezarlarında dua edenler de dâhil olmak üzere kalanları da katlettiler ${ }^{108}$.

105 RDATA, Fon No. 131, Kayıt No. 1, Dosya No. 22, s. 21

106 Baymirza Hayit, (Basmacılar) Türkistan Milli Mücadele Tarihi (1917-1934), Türkiye Diyanet Yayıları, Ankara 1997, s.80.

107 RDATA, Fon No. 131, Kaylt No. 1, Dosya No. 23, s. 17-23

108 RDATA, Fon No. 131, Kayit No. 1, Dosya No. 31, s. 3-8

Belleten, Nisan 2021, Gilt: 85/Say1: 302; 227-277 


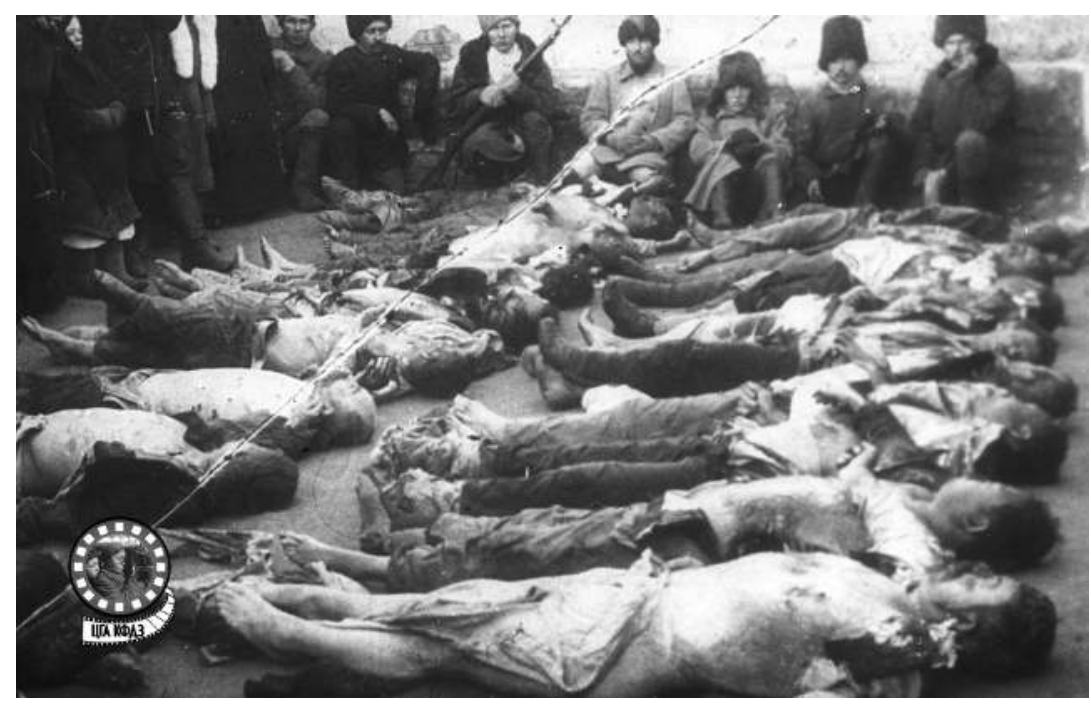

Resim 5: Pavlodar Hapishanesinde Bir Grup Yerli Halkın İdamı ${ }^{109}$

Özbek tarihçisi Ş.Salamov (Barlas) daha önce yayınlanmış olanlarla yeni arşiv belgelerini karşılaştırarak şunları yazmaktadır: "Şamagdiyev'in, arşiv belgelerinden ve "Uluğ Türkistan" gazetesinin makalelerinden yararlanarak ortaya koyduğuna göre: 19181919 tarihleri arasinda yerli ahali idam edilmesinin yam sura Fergana vadisindeki tüm şehirler ve 180 yerleşim yeri yağmaland ve ateşe verildi. Sadece üç gün içinde Hokand'da 10.000, Marglang'da 7.000, Andican'da 6.000, Namangan'da 2.000 ve Bazarkorgan ile Hokand arasindaki yerlesimlerde 4.500 Türk-Müslüman halk öldürüldï. K. K. Rajabov'a göre, eski Oşs şehrinin yaklaşık 2.000 yerli ahalisinin katledildiğgi arşiv belgelerine göre doğrulandı ve buradaki bütün çocuklarn cesetleri baltalanmışt. Şust yerleşkesinde ise 1.500'den fazla yerli halk Ermeniler tarafindan asild"'110. Özbekistan Milli Ansiklopedisi’ne göre, Taşnaklar, Fergana Vadisi'nde yerli halktan kadınlar, yaşlılar ve çocuklar da dahil olmak üzere, üç ay içinde 35.000 kişiyi öldürdü. Salamov, arşiv kaynaklarına ve görgü tanıklarına dayanarak, Bolşeviklerin Taşnak Ermenileri kullanmaya başladığı kıtlk yllarındaki iç savaş sonucunda bir milyondan fazla insan öldügünü ve dönemin Türkistan istatistiklerine göre, açlıktan ölenler hariç yaklaşık 1.700.000 yerli Türk-Müslümanın hayatını yitirdiğini ifade etmektedir ${ }^{111}$. 
Bolşevik yönetiminin güçlenmesi ve genişlemesi, Türkistan'da milyonlarca insanın soykırıma uğramasına yol açtı. Bunların çoğu Taşnakçı şövenist Ermeniler tarafından gerçekleştirildi. 1918-1933 tarihleri arasında Taşnakçı Ermeniler ${ }^{112}$ Türkistan'ın yerli ahalisine karşı "Kızıl Terör" politikasının birinci dönemini tamamladı. Bolşeviklerin, Taşnakçı Ermenileri Türkistan ve Kafkasya’nın yerli halkına karşı kullanma yoluna gitmeleri bir tesadüf değildi. Onlar esasında Ermeni faktörünü iç ve dış politikada güçlü bir şekilde kullanan Çarlık Rusyası'nın geleneğini tevarüs etmiş oldular. Türkistan ve Kafkasya'da, Bolşeviklerin temel amacı, "isyancı" Basmacı hareketinin önünü almak ve Türkistan'ın Sovyetleştirilmesini tamamlamaktı. Taşnakçı Ermeniler, Bolşevikler tarafindan bu politika çerçevesinde Türk-Müslüman halkını Sovyet gücüne zorla tabi kılmak için "cellat" olarak kullanıldı. Sovyet yöneticileri, Ermenilerin kendilerine sadık kalacağını, kalmak zorunda olduklarını düşünüyorlardı ve onların Türkistan'ın yerli ahali ile birleşemeyeceğinden son derece emindiler.

Bolşevikler daha sonra bölgede hâkimiyet kurabilmek ve kendilerini kabullendirebilmek adına ifade tarzında önemli bir değişiklik yaptılar. Nitekim Andican'da 1918 sonunda Türkistan Halk Komiserleri Konseyi tarafindan yayınlanan bir raporda, Taşnakların Sovyet hükümeti ile Türk nüfus arasındaki gerginliğin temel nedeni olduğu ve bölgedeki Bolşevik politikasından sorumlu olan Ermeni liderin şarap tüccarı zengin bir adam olduğu belirtilmektedir ${ }^{113}$. Bolşevikler, bu yolla kendilerini "yerli halk Ermeni zulmünden kurtaranlar" olarak göstermek istiyorlardı. Kendileri tarafindan hazırlanan bu raporlarda Taşnakçı Ermenilerin vahşetini anlatan Bolşevikler, Basmacı hareketini Sovyet karşıtı olarak tanımlarken bir taşla iki kuş vurmuş oluyorlardı: bir taraftan bu vahşetin sebebi olarak Basmacı hareketini suçluyor, diğer taraftan katliamları yapanların kendileri değil Ermeniler olduğunu ileri sürüyorlardı. Bu propaganda ile Türkistan ahalisinin güvenini kazanmaya çalışıorlardı. Bolşevikler Taşnakçı Ermenilerin Fergana Vadisi'ndeki tüm köyleri yakıp yıkmasını bir vahşet olarak tanımladıktan sonra, yerli ahalinin bu vahşeti durduran "Bolşevik yönetimine" sempati duymasını ve taraftar olmasını ümit ediyorlard.

112 Sovyet hâkimiyetinin Kafkasya'da kurulduğu 1920'den itibaren artık Çarlık dönemi siyasi yapılanmaları yaşama imkânı bulamadı. Dolayısıyla Taşnak Cemiyeti de aslen bu tarihten itibaren ortadan kalktı ancak zihniyet olarak bir süre daha devam etti.

113 Riskulov, age., s.108-109.

Belleten, Nisan 2021, Cilt: 85/Sayı: 302; 227-277 
Bolşevikler, Türkistan'da Ermeniler tarafindan gerçekleştirilen katliamları kullanarak yerli nüfusun kendilerine güvenini güçlendirmek maksadıyla yürütülen propaganda kampanyasında kullanılmak üzere bazı talimatlar hazırladılar. Aralık 1918'in başlarında, Basmacı hareketi ile mücadeleye öncülük etmek için Fergana'da mahallî bir operasyon merkezi kuruldu. Bu operasyonu yürüten Acil Durum Komisyonu (Komissiya po Çerezvıçaynım Situatsiyam) organizasyonuyla Fergana şehrinde (Skobelev) Fergana Bölgesel Operasyon Merkezi Komitesi, Askeri Kolej, Bölgesel Yürütme Komitesi ve askeri birliklerin temsilcileri 23 Şubat 1919 'da bir toplantı yaptı. Bu toplantıda Fergana Cephesi Genel Merkezi kuruldu ve cephe üyeleri seçildi. Bu bölgede bölgesel operasyon merkezi, askeri kolej, askeri birimlerden temsilciler, bölgesel, ilçe ve şehir yürütme komitelerinin temsilcilerinin yanısıra oy kullanma hakkı olmamasına rağmen oy kullanan askeri uzmanlar da bulunmaktaydı. Bu raporlarda Taşnakçı Ermenilerin katliamları hakkında malumatlar verilerek Bolşeviklerin bu faciaları kendi menfaatlerine uygun bir şekilde kullanma politikası yürüteceğine dair kayıtlar bulunmaktadır ${ }^{114}$.

\section{Basmacı Hareketi ve Taşnakçı Ermeniler}

Bolşeviklerin ve Taşnakçı Ermenilerin "kızıl kırgın" politikasının ardından Türkistan Muhtariyeti temsilcileri, Milli kurtuluş hareketine başladı. Türkistan Komünist Partisi Merkez Yürütme Komitesi genel sekreteri İvan Solts, bunu 25 Mayıs 1921'de İzvestiya gazetesinde yayınlanan "Basmacılarla Mücadele"(Bor'ba s Basmaçestvom) adlı makalesinde açıkça belirterek şunları yazar: "Hokand Özerk Cumhuriyetine karşı sekiz günlük mücadelede, Basmacı hareketi Ocak 1918'de Rus yönetimine karşı ülke çapinda bir hareket başlattı". Ayrıca makalede Basmacı hareketinin sebepleri de açık bir şekilde ortaya konulmaktaydı. Ona göre, "Hokand olayları" silahsız Türk nüfusa karşı bir misillemeydi. Bu katliamlarn bir sonucu olarak, Türkler uzun süreden beri gelişen olaylara karşı milli bir öfke duyuyorlar ve intikam almak istiyorlardl... yüzlerce hatta binlerce insan Rus yetkililerinin erişiminin ötesinde "Ergeş çetesine" katılmak zorunda kald ${ }^{\prime 115}$. Bu görüşü Türkistan Cephesi karargahı İstihbarat Daire Başkanı askeri komutan Dimitriy Romanoviç Ippolitov da destekleyerek, 1920-1923 yılları arasındaki "Basmacı Hareketi” ne ilişkin raporunda, "Hokand Özerk Cumhuriyetinin çökiuşünün ardından meydana gelen Fergana Basmacılığ hızın arttrdı ve genişledi” ifadesini kullanmaktadir ${ }^{116}$.

114 RDATA, Fon No. 149, Kayit No. 1, Dosya No. 5, s. 7-9

115 RF SSTA, Fon No. 71, Kaylt No. 34, Dosya No. 1527, s. 95-98.

116 RF SSTA, Fon No. 71, Kayıt No. 34, Dosya No. 1585, s. 7-12.

Belleten, Nisan 2021, Cilt: 85/Sayı: 302; 227-277 
Basmacı hareketinin ortaya çıkmasını ve genişlemesini hızlandıran en güçü faktörlerden biri Kolesov'un yürüttüğü "Buhara Harekâtı" sirasındaki olaylardı. Buhara Emirliği, 1868'de Rus İmparatorluğunun işgali altına girdi. Türkistan'da Sovyet iktidarının kurulmasından sonra, RSFSR Halk Komiserleri Konseyi, Buhara'nın bağımsızlığını tanıdı ve Çarlık Rusyası ile daha önce imzalanmış olan işgal anlaşmasını feshetti. Buhara'da Ceditçilik ve Bolşevik yanlısı "Yaş (genç) Buharalılar" hareketi hız kazandı. Buhara Ceditlerinin 1917 yılına kadarki faaliyetleri, esas olarak eğitim - öğretim çerçevesinde yeni usuldeki mektepler teşkil etmek ve basın-yayın aracılığıyla modernist fikirleri yaymaktı.

1910’lu yıllara kadar Yaş Buharahlar adıla anılan bu hareketin bu tarihten sonra ayrışmaya gittikleri görülmektedir. Hareket, aralarında komünizm taraftarları ile komünist olmayanlar şeklinde ikiye ayrıldı. Bilhassa 1917 Şubat ve Ekim devrimleri sonrasında hareket içerisinde Sovyet etkisi ve sosyalizm ideolojisi güçlenmeye başladı. Yaş Buharalılardan bir kısmı Buhara Emirine karşı yardım almak amacıyla Rusya Komünist Partisi'ne yöneldi. Bu durum Yaş Buharalılar arasında komünist fikirlerin artmasına sebebiyet verdi. Nihayet 25 Eylül 1918 tarihinde Taşkent'te, Buhara Komünist Partisi Geçici Merkezi Komitesi kuruldu ve Yaş Buharalıların sol kanadı Komünist Parti çatısı altında birleşti ${ }^{117}$.

Bu gelişme, Buhara'daki ceditçilik hareketinin sslahatçılık karakterinden devrimci sosyalizme dönüşmesini de beraberinde getirmişti. Bolşevik görüşte olanların yegâne amacı Buhara Emiri Âlim Han’ı devirmekti. Diğer grup ise Bir Grup Ceditçi sıfatları ile sadece Emiri devirerek, yönetimi demokratik esaslara göre kurmayı amaçlamaktaydı. 7 Nisan 1917'de Buhara Emiri'nin sarayında toplumun farklı temsilcilerinin katıldığı büyük bir toplantı neticesinde "Said Âlimhan Manifestosu" ilan edildi. Böylece hedeflerine tam olarak ulaşamasalar dahi önemli bir adım atılmış olsa da 8 Nisan'da yapılan gösteri Âlim Han tarafindan basılarak kana bulandı. Bu durum Emir'in ıslahatlara asla yanaşmayacağını göstermişti. Hareketin bu şekilde muhalefet ettikleri Buhara Emiri Âlim Han'1 1910 yılından sonra yaptıkları hamlelerle reform yapmaya ikna etmek için yapılan başarısız girişimlerin ardından, "Yaş Buharalılar" silahlı bir ayaklanma yoluyla hedeflerine ulaşmak ve Taşkent’teki Sovyet hükümetinden destek almak üzere harekete geçtiler. Feyzullah Hocayev ve Mirza Muhittin Yaş Buharalılar delegasyonunu temsilen Kolesov'la Taşkent’te Aralık 1917’de görüştüler. 1917 yılı Aralık ayının başında Bolşevik M.

117 Nurettin Hatunoğlu, "Buhara'daki Ceditçilik Hareketi ve Yaş Buharalılar", SÜTAD, Güz 2015, (38), s. 1-33, s. 4. 
A. Preobrajenski’nin "tavsiyesi”yle Türkistan Halk Komiserleri Konseyi başkanı Bolşevik F. İ. Kolesov'dan, Buhara Emiri'ne karşı yürüttükleri mücadelede askeri yardım verilmesini istediler. Bu görüşme sonrasında Feyzullah Hocayev hareketin literliğine seçildi. Daha sonra da Moskova'ya giderek destek aradılar. 1920 yllı Ocak ayında Taşkent'e yeniden gelen Feyzullah Hocayev, Yaş Buharalıların sol kısmını temsil etmek üzere Yaş Buharalı İnkılapçılar Partisi'ni kurdu ${ }^{118}$.

Mart 1918'de Türkistan Bolşevik yönetimi, Buhara Emirliği halkının yüksek ruhlu olduğu sloganıyla Emirliği devirmek için girişimlerde bulundu. Ancak P.A.Kobozev anılarında o zamanki Türkistan Halk Komiseri F. İ. Kolesov liderliğindeki faaliyetlerin başarısız olduğunu belirtmektedir ${ }^{119}$. Bolşevikler bölgeye geldiklerinde ayrışmış olan grubu birleştirerek Emiri devirmek ve yönetime el koymaları hususunda isyana teşvik ettiler. Nihayet 29 Ağustos 1920'de Said Âlimhan Buhara'yı terk etti ve 6 Ekim 1920 tarihinde gerçekleşeşn 1. Genel Buhara Halk Vekilleri Kurultayı'nda Feyzullah Hocayev BHSR Halk Nazırları Sovyeti'nin başkanlığına seçildi ${ }^{120}$.

Kızıl Ordunun önde gelen isimlerinden İ. Kuts ${ }^{121}$ anılarında bu meseleye temasla: "Seyid Alimhan ile savaşmak bizim çıkarlanmıza uygun değildi... Türkistan zaten kanla boğulmuştu. Buhara seferi için sadece bin kişilik bir birlik oluşturuldu. Bunlar Türkistan'ın dört bir yanndan toplanmış olan düzensiz ve askeri eğitimi zaynf silahl oluşumlard..." demektedir ${ }^{122}$. Askeri hatalara ek olarak Kolesov'un operasyonu, bölgede Bolşevik hükümetin oluşumu ve faaliyetlerinin bir başka çarpıcı göstergesi oldu. Buhara ve çevresinde Kızıl Ordu birimlerinin ortaya çımasına büyük soygunlar ve

118 Veli Savaş Yelok, "Feyzullah Hocayev ve Cedit Hareketi”, Türk Dünyası Bilgeler Zirvesi: Gönül Sultanlan Buluşması 26-28 Mayıs 2014, Eskişehir 2013, Türk Dünyası Kültür Başkenti Ajansı (TDKB), Eskişehir 2014, s. 423-428, s. 425 vd.

119 RF SSTA, Fon No. 131, Kayıt No. 1, Dosya No. 25, s. 23-29

120 Yelok, agm., s. 427.

121 Ivan Fedoroviç Kuts - 25 Ocak 1900'de Rusya'nın Krasnovosk şehrinde doğdu. Sovyet askeri lideri, orgeneral. Eylül 1918'de Kızıl Ordu saflarına alındı ve Ekim ayında Semerkand'taki Bolşevik süvari birliklerinin başına getirildi, Mart 1919'da Semerkand'ta Basmacılara karşı gerçekleştirilen savaşın başkanlığına getirildi. Mayıs ayında Taşkent’teki Bolşeviklerin süvari birimindeki Türkistan konsolide komuta derslerine katılmaya gönderildi ve daha sonra aynı yılın Kasım ayında 2. Alay komutanlığına atandı. II. Dünya savaşına katıldı, savaş sonrası M. F. Frunze Askeri Akademisi'nde, 1955'ten itibaren Rusya'nın Smolensk Beden Eğitimi Enstitüsü Askeri Bölümü'nün başkanlığını yaptı. 1957'de orgeneral oldu. Yedek asker olarak emekliye ayrılan İ. F. Kuts, 22 Ağustos 1989'da Moskova'da öldü. Geniş bilgi için bk. I. F. Kuts, Gody v Sedle. Voyennyye Memuary, Voyenizdat, Moskva 1964. s. 3-7.

122 I. F. Kuts, Godı v Sedle, Voyenizdat, Moskva 1964, s. 27-31. 
yerli ahalinin öldürülmesi eşlik etti. Taşkent'te yayınlanan "Naşa Gazeta"nın 28 Nisan 1918 tarihli nüshasinda yaymlanan bir haberde: "O zamanlar Türkistan Halk Komiseri Konseyi Başkam F. I. Kolesov tarafindan yürütïlen harekat, Buhara'daki siyasi hava üzerinde derin bir etki yapt ve Rusya'ya karşı tutumu kökten değţştirdi. Kampanya başarısız oldu ve Bolşsevik vahşeti zulme uğrayan Buhara halkm kızdordı ve Türkistan'da Milli Kurtuluş mücadelesinin başlamasma sebep oldu" denilerek aynı duruma temas edilmektedir ${ }^{123}$. P. A. Kobozev kendi anılarında konuyla ilgili olarak; "Kizıl Ordu askerleri, Hokand ve Buhara'da para, sı̆̆ır, atlar ve diğer mallan yağmaladıktan sonra geri döndü. Kižl Ordu çalnnan mülkün bir kısmmn hazineye ve Bolşevik hükümetine devretti. Sonuç olarak, yerel halk arasinda artan protestolar silahlı muhalefete dönü̈smeye başladı" demektedir. Bu durum Türkistan'da Basmacı hareketinin ortaya çıkışının mühim sebeplerinden birini izah etmektedir. Kızıl Ordu Fergana birliklerinin komutanı F. Safonov daha sonra konuya ilişkin olarak: "Bütün insanlarn mallan yağmalandı, tecavïze uğradılar ve dövüldüler. Bolşeviklerin politikası kana susamıstı, böylece Sovyet birlikleri daha sonra Basmacı hareketine kathlan Türkleri katletti" demişti ${ }^{124}$.

1919'dan başlayarak Fergana Vadisi, Türkistan'daki Basmacı hareketinin yoğunlaştığı merkezlerden biri haline geldi. 1918'in sonunda Bolşeviklere karşı toplamda 7.000 kişiden oluşan 40'a yakın milli birlik oluşturuldu. Bolşeviklerle askeri çatışmaların önlenmesi için Basmacılar köylere ve küçük kasabalara saldırılar organize etti, Sovyet hükümetinin üyelerini öldürdü, küçük askeri garnizonları yok etti ve uzak bölgelerde, genellikle dağlar veya kumların arasında saklandı ${ }^{125}$. Sovyet hükümeti, vergileri artıran ve kendilerine katılmayan köylere saldırılar düzenleyen "partizan milli kurtuluş" hareketine karşı geleneksel yöntemlerini kullanarak kendi açısından sorunu çözmeye çalıştı. 1922'de Türkistan Halk Komiseri Konseyi Başkanı K. Atabaev, Basmacılarla mücadelenin gidişatını analiz ederek: "Bir keresinde Basmacılarn silah ve kulç̧la yok etmeyi düşündük. Bu amaçla, büyük ve küçük köylerdeki "bütün nüfus" acımasızca katledildi ve sonuç olarak insanlar Sovyet hükümetinden uzaklaştı. Genel olarak, Fergana'yn istilada bizim için yol açmadı. Insanlar bizi dïşman belledi ${ }^{\gg 126}$ demektedir.

123 RF SSTA, Fon No. 71, Kayit No. 34, Dosya No. 1480, s. 270.

124 RF SSTA, Fon No. 71, Kaylt No. 34, Dosya No. 1503, s. 2-4.

125 A. I. Zevelev - Yu. A. Polyakov - L. B. Şişkina, Basmaçestıo: Pravda İstorii $i$ Vımısel Falsifikatorov, Moskva Misl 1986, s. 255

126 D. F. Şevçenko, Formirovaniye Massovogo Basmaçeskogo Dvijeniya v Sredney Azii Posle Oktyabrskoy Revolyutsii, Irkutsk 2006, s. 59.

Belleten, Nisan 2021, Cilt: 85/Sayı: 302; 227-277 
Bu şekilde gittikçe artan Bolşevik zulüm ve baskısı Moskova'dan bölgeye gelmiş olan (Batum'dan Buhara'ya) Enver Paşa liderliğindeki Basmacıların mücadelesi ile Türk nüfusun birleşmesine yol açtı ve direniş hareketini daha da güçlendirdi. Buhara Emiri ilan edilen Enver Paşa'nın gayretleriyle bölgede Bolşeviklere yönelik düşmanlık arttı ve sonuçta Basmacıların sayısı günden güne artarak 8-10 bin kişiye ulaşt1 ${ }^{127}$. Bu durumda Türkistan'da bir araya gelen Bolşevikler Taşnakçı Ermenileri kullanma politikasına yöneldi. Bolşevik istihbarat unsurlarmndan elde edilen malumata göre burada bulunan Ermenilerin birçoğu Osmanlı topraklarından kaçarak Türkistan'a gelen Taşnak Partisi'nin üyeleriydiler. Bunlar Türkleri düşman olarak görmekteydi ${ }^{128}$. Hokand'ın yeni şehir kısmının Sovyet yönetimi eski şehre yapılan saldırı sırasında Ermenileri silahlandırdı ve daha sonra 100 kişilik bir Ermeni askeri grup oluşturdu. Bu grup bölgedeki Rus nüfusu ile Bolşeviklerin temsilciliği görevini yaptı. Basmacı hareketine karşı savaşta merkezi bir rol oynadı ve 1922'ye kadar, silahlı Taşnak Ermeni birlikleri yerli Türk halka karşı acımasız bir soykırıma girişti ${ }^{129}$. SSCB'nin Siyasi Güvenlik Organı olan GPU-OGPU'nun ${ }^{130}$ faaliyetleri, Türkistan'daki Basmacı hareketini durdurmak amacıyla ilk safhada 1922'den 1926'ya kadar GPU-OGPU birlikleri ve Türkistan Cephesi birlikleri kullanıldı. Bunlar ortak operasyonlarla Basmacıların imhasına katıldılar. İkinci aşamada, yani 1926'dan 1933'e kadar OGPU'nun Türkistan askeri bölgesindeki az sayıda askerinin katılımıyla Basmacı birliklerinin kalıntıları iddiasıyla pek çok insan imha edildi ${ }^{131}$.

127 Mehmet Yılmaz-Ferudun Ata, "Buhara Cumhuriyeti Ve Basmacılık Hareketi Hakkında İki Rapor", Türkiyat Araştrmalan Dergisi, S. 15 (2004), s. 205-225, s. 210 vd.

128 M. Buttino, "Ethnicité et politique dans la guerre civile: a propos du Basmačestvo au Fergana". Cahiers du monde russe. T. 38, Buttin, 1997, s. 194-223.

129 ÖCMDA, Fon No. 17, Kayit No. 1, Dosya No. 1219, s. 130-135.

130 Sovyetlerin Halk Komiserliğinin yetkileri üzerinde, RSFSR'nin NKVD'si (SSCB'nin İçişleri Halk Komiserliği) ve Sovyet cumhuriyetlerinin güvenlik yapıları altında 6 Şubat 1922'de oluşturulan Devlet Siyasi İdaresi temelinde 15 Kasım 1923’te kuruldu. Çeka'nın (RSFSR Halk Komiserleri Konseyinde Bütün Rusya'nın Devrim ve Sabotajla Mücadele Olağanüstü Komisyonu) işlevlerinin bir kısmı GPU ve OGPU'ya devredildi (açık karşı-devrimci eylemleri bastırmak, casuslukla savaşmak, sınırları korumak, istihbarat servisi yapmak vs.). 1929'da, zorunlu çalışma kamplarının bir kısmı OGPU'nun yetkisi altına girdi. Geniş bilgi için bk. O. B. Mozohin, Represii v Tsifrah i Dokumentah. Deyatelnost VÇK-OGPU-NKVDMGB (1918-1953), Moskva 2018.

131 V. F. Nekrasov, Na Straje Interesov Sovetskogo Gosudarstva: İstoriya Stroitelstva Voysk VÇK-OGPU-NKVDMVD, Voyenizdat, Moskva 1983, s. 17-18. 
İk aşamada, özellikle Fergana Vadisi ile Alay ve Arça vadilerinin yaylalarında, Sirderya ve Semerkant bölgelerinde, Doğu Buhara, Hive, Karakum, Krasnovodsk bölgesinde, Narın nehri ve Güney ile Kuzey Kazakistan'da Basmacı hareketi çok aktifti. Dağlara ve çöllere çekilen Basmacı askeri birliklerine ulaşılamadı. Basmacılar yoğun nüfuslu bölgelere atlarla saldırılar düzenledi, Sovyet resmi görevlilerini ve Bolşevik hükümeti destekçilerini öldürdü ve yerli halkla irtibat kurdu. Basmacılar çete taktiklerine başvurdular, düzenli Bolşevik birliklerinin ana kuvvetleriyle çatışmaktan kaçındılar ve küçük veya güvenlik bakımından zayıf Kızıl Ordu güçlerine saldırdılar ve sonra hızla geri çekilmeye çalıştılar ${ }^{132}$.

Basmacı birliklerine karşı, GPU-OGPU askeri birimleri; Taşnakçı Ermenilerle birlikte: Kızıl Ordu yönetim birimleri tarafindan yönetilen özel ortak operasyonlar sırasında büyük Basmacı gruplarının tasfiyesine katılmak; kapsamlı askeri keşif operasyonlarının yürütülmesi; önemli devlet kurumlarının ve demiryolu ulaşım tesislerinin korunması; yerli halka hasat ve sosyalist inşaat faaliyetlerinde yardım etmek; Sovyet hükümetinin amaç ve hedefleri hakkında yerel halk arasında partinin siyasi propaganda çalışmalarını yapmak gibi görevleri üstlenmişti. Ayrıca okullarla birlikte kurulan kolhoz ve sovhozlara komünistlerin desteğini sağlamak da bu görevler arasındayd $1^{133}$. OGPU ile Taşnak Ermenilerin askeri birliklerinin faaliyetleri hakkında T. Ryskulov: "Fergana bölgesinde "Ermeni Dashnaktsutyun Partisi'nin" kıskkrtıcı ve kanla boyanmıs siyasi tutumu öncülïk yapmıştır. Taşnaklar Basmacılarn tutuklamak için genellikle Sart kadnnlanna tecavüz etti ve çocuklarm doğrayarak katletti. Bütün bunlar dini fanatizme ve Müslüman nüfusun duygularna etki etti ve onlar şehirlerle köyleri brrakmaya mecbur kaldllar" demektedir ${ }^{134}$.

1920 yılına doğru, Türkistan'daki Basmacı hareketine karşı savaşmak için Türkistan cephesinde, Orenburg, Ural ve Aktobe bölgelerinin 3 piyade ve 4 süvari bölüğü ve 36 bin kişiden oluşan kuvvetler çekilerek 114.000 kişiden oluşan Kolordu teşkil edildi. Bu orduya Taşnak askerleri de eklendi ${ }^{135}$. Buna göre 1 Şubat 1922'de Rusya Komünist Bolşevik Partisi Merkez Komitesi Politbürosu, V. Kuybışev, I. Stalin, F. Hojayev, G. Çiçerin'den oluşan bir komisyon tarafindan hazırlanan "Buhara

132 Sbornik Shem $i$ Tablits po Organizatsii i Voorujeniyu Soyedineniy $i$ Voinskih Çastey Krasnoy Armï, Leningrad 1943, s. 64 .

133 D. A. Alimova, Turkestan v Naçale XX Veka: K Istorii Istokov Natsionalnoy Nezavisimosti, Glavnaya Redaktsiya İzdatelskogo-Poligrafiçeskogo Kontserna "Şarq", Taşkent 2020, s. 197-202.

134 Riskulov, age., s. 122.

135 Soveşenno Sekretno! Tolko Dla Komandovaniya. Dokumentr i Material, Moskva 1987, s. 35-42.

Belleten, Nisan 2021, Cilt: 85/Sayı: 302; 227-277 
Meselesi Hakkinda" özel bir kararnameyi kabul etti. Bu Kararname, RSFSR'nin parti birimleri ile Buhara ve Horezm Halk Cumhuriyetlerinin parti örgütleri arasındaki bağları güçlendirip, Kızıl Ordu birimlerini Basmacılara karşı birleştirmeyi, Buhara özel bölgesini "karşı-devrimci unsurlardan" hızlıca temizlemeyi ve parti lehine bir hava yaratmak için yerel halk arasındaki siyasi çalışmaları güçlendirmeyi amaçlıyordu ${ }^{136}$. Bunun yanı sıra Sovyet yetkililerinin aktif katılımı ile yaklaşık 2 bin kişilik "Fergana Köylï Ordusu" oluşturuldu ve genel karargâhı kuruldu. Daha sonra, Sovyetler bu orduya Taşnak Ermenilerini ekledi ve onlarla birlikte silahlar ve diğer birçok askeri mühimmat tahsis etti. Ermeni askerleri "isyanci" Basmacılara karşı Kızıl Ordu birlikleri ile birlikte aktif olarak çatışmalara katıldı. Madaminbek ve Halhoja Basmacı birlikleri ile ilk çatışmalardan biri Kasım 1918'in başlarında meydana geldi ve bu çatısmada Basmacılar başarısız oldular. Daha sonra Basmacılar, Güney Kazakistan'ın Sozak bölgesine çekilmeye mecbur kaldılar. Bu bölgeye gelen Taşnakçı Ermeni askerleri yerleşkeyi ele geçirdi ve burada vahşi ve kanlı bir pogrom gerçekleştirdi. Bu olaylara tanık olan yerliler gördüklerini şöyle izah ettiler: "bir yığın harabe, kül ve yarmm yanmıs cesetler yığmn kalmıştı. Hayatta kalan köy sakinleri, evlerini terk ederek, mezarliklara siğmnaya mecbur kald $\imath^{137}$.

136 KC MDA, (Kazakistan Cumhuriyeti Merkezi Devlet Arşivi) Fon No. 139, Kayit No. 4, Dosya No. 15, s. 1-11.

137 P. Alekseenko, Krestyanskoye Vosstaniye v Fergane, Taşkent 1931, s. 23-24. 


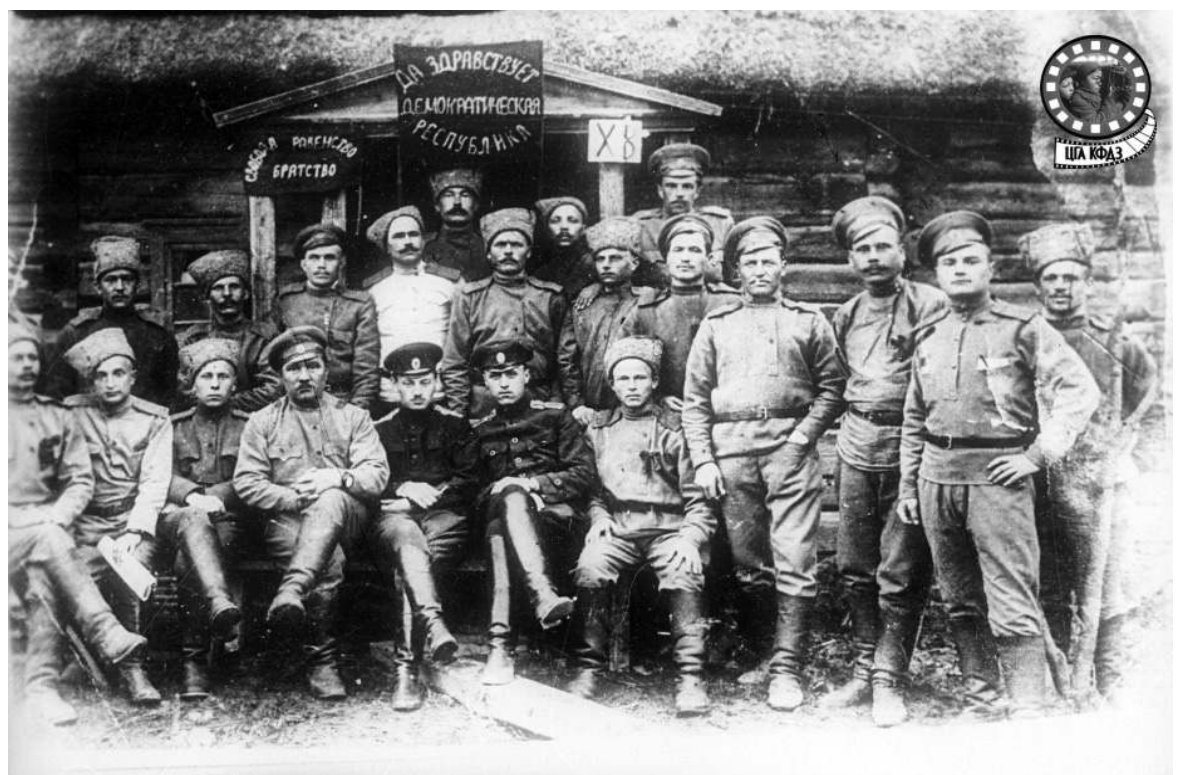

Resim 5: Semireçi'de (Yedisu) Ekim Devrimi ve İç Savaşa Katılan Bir Grup Asker ${ }^{138}$

20 Nisan 1922'de, Umum Rusya Komünist Partisi Merkez Komitesi Politbürosu dikkatini Türkistan Cephesine vererek Gürcü G. Ordjonikidze'yi ${ }^{139}$ bölgedeki durumu düzeltmesi için buraya göndermeye karar verdi. Politbüro, Basmacı hareketi tamamen ortadan kaldırılıncaya kadar Türkistan'da sıkıyönetim ilan etti. Bölgedeki vaziyet Buhara Cumhuriyeti askeri komiseri Abdulahai Arifov'un Enver Paşa'nın yardımcısı olarak atandığı 1922'nin baharında değişti ${ }^{140}$. Mart sonu ve Nisan 1922'nin başlarında Enver Paşa, harekete kendi ordusuna ek olarak 300 asker ve iki kervanla nakledilen silahlar sağladı. Tüfekler ve mühimmatın yanı sıra altı da top temin etti ${ }^{141}$. Bu yardımla durumunun elverişli hale geldiğini düşünen

138 KC MDFFBSKA, Arx. 8-654.

139 Sergo Ordzhonikidze (Grigory Konstantinoviç) - Sovyet politikacı ve devlet adamı. 1903'te Sosyal Demokratik çevreye katıldı. Bolşevik Parti içerisinde Sergo olarak biliniyordu. 1905'te Tıp Okulu'ndan mezun oldu. Ordjonikidze, İç Savaş sırasında çeşitli cepheler ve ordulardan oluşan Devrimci Askeri Konsey üyesi olan Kuzey Kafkasya Savunma Konseyi’nin başkanıydı (Aralık 1918 - Haziran 1919). Bu sırada Stalin'e yaklaştı. Geniş bilgi için bk. G. K (Sergo) Ordzhonikidze, İzbrannıye Statyi i Reçi. 19181937, Gospolitizdat, Moskva 1945.

140 Yu. A. Polyakov - A. İ. Çugunov, Konets Basmaçestva, Nauka, Moskva 1976, s. 90-102.

141 KC MDA, Fon No. 2225, Kayıt No. 2, Dosya No. 45, s.115-120.

Belleten, Nisan 2021, Cilt: 85/Sayı: 302; 227-277 
Enver Paşa, 19 Mayıs 1922'de Sovyet hükümetine gönderdiği ültimatomda Kızıl Ordu birliklerinin Hive, Buhara ve Türkistan'dan çekilmesini istediğini, aksi takdirde açık bir savaşa gideceğini belirtti. Bu mektupta Enver Paşa kendisini Hive, Buhara ve Türkistan ordularının komutanı ilan etti ${ }^{142}$. Sovyet yönetimi mevcut durumu göz önünde tutarak, özel Buhara kuvvetleri grubu oluşturdu. N. Kakurin ve P. Pavlov'un komutasındaki bu birlikler yaklaşı 8.000 silahlı askerden oluşuyordu ve 20 makinalı tüfeğe sahipti. Komünist Parti'nin ilk komutanlarından Rus devrimcisi, J. Peters ve RSFSR komutanı S.Kamenev, Enver Paşa'ya karşı operasyonlar yürütmek üzere Buhara'ya gönderildi. Keza, Doğu Buhara için bir yardım hazırlığı görüntüsü altında ayrı bir piyade tugayı oluşturuldu. Bu amaçla, GPU Ordusunun 84. bağımsız piyade taburu Almatı'da kuruldu $^{143}$. 15 Haziran 1922'de; Buhara kuvvetleri grubunun birimleri, Kizıl Ordu birimleri, gönüllüleri ve Buhara halkının milislerinden oluşan hükümet kuvvetleri Basmacıların saldırısına uğradı. A. Çugunov ve G. Polyakov'a göre Birinci Süvari Tugayı, Sekizinci Süvari Tugayı ve Onbirinci Süvari Tümeni de bu askeri harekâtta görev $\operatorname{ald}_{1}{ }^{144}$. Bu arada hareketin liderliğini yapan Enver Paşa Tacikistan'da, Belçivan yakınlarında 4 Ağustos 1922'de Kurban Bayramı sırasında Yakov Arkadiyeviç Melkumov adındaki bir Ermeni subayın idaresindeki kızıl birlik tarafindan şehit edildi.

Türkistan'daki Basmacı hareketinin genişleyerek büyümesi ve Bolşevik yetkililer tarafindan onu bastırmak için çok sayıda Kızılordu birlikleri ile Taşnak Ermeni askerlerinin gönderilmesi, Basmacı hareketinin Bolşevikler için ne kadar ciddi bir tehlike yarattı̆̆ını göstermektedir. 15-18 Ağustos 1922 tarihleri arasında düzenlenen Üçüncü Uluslararası Halk Temsilcileri Kongresi, Enver Paşa’ya karşı düzenlenen saldırıların sonuçlarını açıkladı. Özellikle Buhara Sovyetleri Kongresi, Kızıl Ordunun uluslararası misyonunu vurgulayarak Rus Kızıl Ordusunu kişisel kazanım için değil, Buhara Halk Sovyeti Cumhuriyeti topraklarını kurtarmak ve mevcut Basmacı hareketini kökünden kazımak için Buhara'ya çă̆ırd ${ }^{145}$.

142 A. İ. Çugunov, Borba na Granitse 1917-1928 (İz İstorii Pograniçnh Voysk SSSR), Moskva 1980, s. 112-115.

143 V. N. Bogdanov - S. P. Osadçiy - V. V. Terehov, Armiya $i$ Vnutrenniye Voyska v Protivopovstançeskoy $i$ Protivopartizanskoy Borbe. Mirovoy Opt i Sovremennost, Moskova 1997, s. 87.

144 Bogdanov, age., s. 98-102.

145 Syezdr Sovetov Soyuza SSR, Soyuznı i Avtonommih Sovetskih Sotsialistiçeskih Respublik. Sbornik Dokumentov v III Tomah, II Tom, Moskva 1960, s. 588. 
Türkistan'da Bolşeviklerin elde ettikleri başarı ile Basmacı hareketinin durdurulmasının ardından bölgenin birçok kesimlerinde milli ayaklanmalar 1930'lara ve hatta 1950'lere kadar devam etmiştir. Omarbekov'a göre Sovyet soykırımına karşı 1929-1931 yılları arasında Kazakistan'ın Tastakköpür, Bostandık, Batpakkara, Sozak, Sarısu, Şubar-Balkaş-Şokpar, Öskemen ve Zıryan, Yedisu, Irgız, Karakum, Abıralı, Şubartau bölgelerinde yaklaşık 372 milli ayaklanma gerçekleşti ${ }^{146}$. İstihbarat raporlarında Kızıl Ordu'nun Basmacı gruplarına karşı operasyonları sırasında çok kayıplar verdiği ifade edilmektedir. Örneğin, Rus Askeri Devlet Arşivi'ne göre, Mayıs 1922'nin ortalarına kadar, Türkistan'daki 26.061 Basmacı, Bolşevik yönetimini henüz tanımamış ve Kızıl Orduya karşı ayaklanmalar düzenlemiştir ${ }^{147}$. 15 Nisan 1923 'te, Bolşevik E.Sklyanskiy ve Çeka'nın kurucularından biri olan İ.Unşliht, Türkistan Devrimci Askeri Konseyi ve GPU 823/215 nolu ortak bir karar aldılar. Bu karara göre Basmacı ve "Eşkiya" gruplarla mücadele meselesi, sahadaki savaşların yürütülmesi yetkisi GPU'nun askerlerine devredilmiştir. Buyrukta Kızıl Ordu ve GPU askeri birliklerinin ortak operasyonlarının "eşkiyalı̆̆ı" ortadan kaldırmak için Buhara, Semerkant ve Fergana bölgelerinde, Horezm Cumhuriyetinde ve Türkistan cephesindeki diğer birçok bölgede başarıyla yürütüldüğu kaydedilmiştir ${ }^{148}$.

Bütün bu aktarılanlardan açıkça görülmektedir ki, "Basmacıllk", SSCB döneminde araştırmacılar tarafindan Sovyet ideolojisi çerçevesinde değerlendirilmiş ve sunulmuştur. Ancak bu taraflı bakış açısıyla yapılan araştırmalarda da Kızılordu'nun yürüttügü askeri harekât sırasında Ermenilerden oluşan birliklerin özellikle kullanıldığını ortaya koymaktadır. Sovyet-Rus tarihçiliğinde Basmacı hareketi kasıtlı olarak "silahlı eşkiya saldırıları" şeklinde tanımlanmış olsa da, aslında bu hareket Türkistan'da Bolşeviklerin sömürge politikası ile Taşnak Ermenilerin işgal ve zulmüne karşı milli bir kurtuluş savaşı olmuştur. Türkistan'da neredeyse elinde silah tutan bütün Türklerin katıldığı bu hareket, Bolşevikler ve Kızıl Ordu tarafından "feodal zengin elitin" ve "gerici din adamlarını" önemsiz bir eylemi olarak nitelendirildi. Bolşevikler yaptıkları güçlü propagandada, Milli Mücadeleyi başlatan Cedidçileri "yeni bir ulusal burjuvazi” olarak adlandırmışlardır. Türkistan'da Sovyet sistemi kurulduktan sonra ise Cedidçiler Basmacı eşkiya kategorisine girdi

146 Talas Omarbekov, 1929-1931 Fıldanndağı Hahq Koterilisteri, Zertteu, Arıs, Almatı 2018.

147 RDATA, Fon No. 7, Kayıt No. 2, Dosya No. 466, s. 55-60.

148 Vnutrenniye Voyska v Godı Mirnogo Sotsialistiçeskogo Stroitelstva 1922-1941, Dokumentı i Materialı, Moskva 1977, s. 17. 
ve OGPU'nun idamına mahkum bırakıldı. Bütün bu olaylarda Kızıl Ordu içindeki Taşnak Ermenilerin varlığı oldukça açık tarihi bir vakıadır.

\section{Sonuç}

Rusya'nın genişleme politikalarında Ermenilerle stratejik ortaklıklarının tarihi 19. asrın başına kadar gider. Kafkasya, İran, Anadolu ve Türkistan coğrafyasındaki Rus işgal ve genişleme hareketlerinde Rus ordusunda bizatihi savaşan Ermeniler olduğu gibi bu genişleme ve uygun bulunan kolonizasyonlarda Ermenilerin de iskân edildiği görülmektedir. Bilhassa Rus Çarlığı tarafindan Kafkasya'da Azerbaycan Türklerinin yaşadığı topraklarda Ermenilerin üstün ve avantajlı konuma getirildikleri bilinmektedir. Anadolu'da da Osmanlı Devleti'ni parçalama ve bu topraklardan pay ve etki sahibi olabilmek adına Doğu Anadolu'da bağımsız bir Ermeni yurdu kurma düşüncelerini en azından destekler görünmekteydi. Rus Çarlığı ile Ermeniler arasında ortaya çıkan bu işbirliği Rusya'nın Türkistan işgalinde de gerçekleşti. 19. asınn ikinci yarısından itibaren Türkistan coğrafyasına Rus işgali ve kolonizasyonu dâhilinde Ermeniler bölgeye gönderildi. Bölgede istihdam edilen Ermeniler bölgede daima avantajlı bir konumda olldular. Memuriyetlerde ve aldıkları ücretler açısından daima iyi durumda bulunan Ermenilerden bazıları da ticaret erbabı oldular. Bilhassa Kafkasya petrolünde ve Hazar petrol taşımacılığında önemli pay sahibi olan Ermenilerin Kazak petrolünde de ayrıcalık sahibi olduğu anlaşılmaktadır. Bu şekilde güç kazanan Ermeniler, Rusların bölgedeki varlığının güçlendirilmesi ve Ruslaştırma politikalarının en büyük destekçisi olmuşlardır.

Çarlık döneminde Ermenilerin bu şekilde bölgede etkin ve etkili konumları Bolşevik İhtilali sonrasında da aynen devam ettirildi. Rejimi yerleştirmede büyük zorluklar yaşayan Bolşevikler bölgede ortaya çıkan Milli Mücadele'nin kanlı bir şekilde bastırılmasında Ermenilere önemli görevler verdiler. Basmacı hareketinin bastırılmasında Taşnak Ermenilerden oluşan askeri birlikler kullanıldı. Aynı durum Kafkasya için de geçerliydi. Sovyetlerin lehine bölge halkına soykırıma varan bir politika uygulandı. Bu sebeple Basmacı hareketi Türkistan'daki Türk-Müslüman halklarının milli kimliğini koruyamadı ve Bolşevik rejimi bölgede Ermeniler eliyle gerçekleştirilen kanlı hamlelerle yer edindi. Çarlık döneminde bölgede önemli bir güç haline getirilen Ermeni unsur, daha sonra Bolşevik rejiminin yerleşmesinde yine kanlı bir el olmuştur. Bu durum Çarlık'tan Bolşevik rejimine Ermenilerin bölge işgal ve hakimiyetinde kullanılmasında bir devamlllğın bulunduğunu göstermektedir. 
KAYNAKLAR

\section{Arşiv Kaynakları}

KC MDFFBSKA (Kazakistan Cumhuriyeti Merkezi Devlet Film ve Fotoğraf Belgeleri ile Ses Kayıtları Arşivi)

Arx. 2-41-719.

Arx. 2-34451

Arx. 2-35221.

Arx. 2-36213

Arx. 5-3448.

Arx. 8-654.

\section{KCMDA (Kazakistan Cumhuriyeti Merkezi Devlet Arşivi)}

KCMDA, Fon No. 41, Kayıt No. 1, Dosya No. 258.

KCMDA, Fon No. 44, Kayıt No. 1, Dosya No. 4144.

KCMDA, Fon No. 44, Kayıt No. 1, Dosya No. 48806.

KCMDA, Fon No. 44, Kayıt No. 1, Dosya No. 48940.

KCMDA, Fon No. 44, Kayıt No. 1, Dosya No. 810.

KCMDA, Fon No. 85, Kaylt No. 1, Dosya No. 87.

KCMDA, Fon No. 139, Kayıt No. 4, Dosya No. 15.

KCMDA, Fon No. 450, Kayıt No. 1, Dosya No. 1.

KGMDA, Fon No. 450, Kayıt No. 1, Dosya No. 2.

KCMDA, Fon No. 679, Kayit No. 1, Dosya No. 129.

KCMDA, Fon No. 679, Kayıt No. 1, Dosya No. 156.

KCMDA, Fon No. 679, Kayit No. 1, Dosya No. 163.

KCMDA, Fon No. 679, Kayıt No. 1, Dosya No. 165.

KCMDA, Fon No. 679, Kayıt No. 1, Dosya No. 165.

KCMDA, Fon No. 679, Kayıt No. 1, Dosya No. 172. 
KGMDA, Fon No. 680, Kayıt No. 1, Dosya No. 14.

KCMDA, Fon No. 680, Kayit No. 1, Dosya No. 4.

KCMDA, Fon No. 680, Kayit No. 1, Dosya No. 5.

KGMDA, Fon No. 681, Kayıt No. 1, Dosya No. 16.

KCMDA, Fon No. 681, Kayıt No. 1, Dosya No. 3.

KCMDA, Fon No. 681, Kaylt No. 1, Dosya No. 4.

KCMDA, Fon No. 2225, Kayit No. 2, Dosya No. 45.

KCMDA, Fon No. 1479, Kayıt No. 2, Dosya No. 711.

ÖCMDA (Özbekistan Gumhuriyeti Merkezi Devlet Arşivi)

Fon No. I-717, Kaylt No. 1, Dosya No. 52.

Fon No. 17, Kayıt No. 1, Dosya No. 1219.

RDAA (Rusya Devlet Askeri Arşivi)

Fon No. 25896, Kayıt No. 1, Dosya No. 2-68.

RDATA (Rusya Devlet Askeri Tarih Arşivi)

Fon No. 7, Kayıt No. 2, Dosya No. 466.

Fon No. 131, Kaylt No. 1, Dosya No. 17.

Fon No. 131, Kayit No. 1, Dosya No. 22.

Fon No. 131, Kaylt No. 1, Dosya No. 23.

Fon No. 131, Kayıt No. 1, Dosya No. 31.

Fon No. 149, Kayit No. 1, Dosya No. 198.

Fon No. 149, Kayit No. 1, Dosya No. 5.

RF SOMDA (Rusya Federasyonu Sovyet Ordusu Merkez Devlet Arşivi),

Fon No. 110, Kaylt No. 1, Dosya No. 71.

RF SSTA (Rusya Federasyonu Sosyal-Siyasi Tarih Arşivi)

Fon No. 71, Kayıt No. 34, Dosya No. 1480.

Fon No. 71, Kaylt No. 34, Dosya No. 1503. 
Fon No. 71, Kayıt No. 34, Dosya No. 1527.

Fon No. 71, Kayit No. 34, Dosya No. 1585.

Fon No. 71, Kaylt No. 34, Dosya No. 1632.

Fon No. 131, Kayit No. 1, Dosya No. 25.

Fon No. 133, Kayit No. 1, Dosya No. 24.

\section{Araştırma ve İnceleme Eserler}

A. Ş. Kıdırbayev, "Armyanskaya Diaspora i Daşnaktsyutun v Turkestane. 19171921 Godı", Vostoçny Arhiv, No. 2 (28), İnstitut Vostokovedeniya Rossiyskoy Akademii Nauk, Moskva 2013.

Adres-Spravoçnik Zakaspiyskoy Oblasti za 1915 God, Aşhabad 1915.

Agzamkhodzhayev, S., Istoriya Turkestanskoy Avtonomiï, Taşkent 2005.

Alekseenko, N. V., Naseleniye Dorevolutsionnogo Kazahstana, Alma-Ata 1981.

Alekseenko, P., Krestyanskoye Vosstaniye v Fergane, Taşkent 1931.

Alekseenko, P. T., Ç.to Takoye Basmaçestvo? Taşkent 1931.

Alimova, D. A., Turkestan v Naçale XX Veka: K İstorii İstokov Natsionalnoy Nezavisimosti, Glavnaya Redaktsiya İzdatelskogo-Poligrafiçeskogo Kontserna "Şarq", Taşkent 2000.

Aminov, A. M. - Babahojayev, A. H., Ekonomiçeskiye Posledstviya Prosoyedineniya Sredney Azii k Rossii, Taşkent- Uzbekistan 1966.

Amiryants, I. A. - Grigoryants, A. A., Armyane v Sredney Azii. Sovremennoye Razvitiye Etniçeskih Grupp Sredney Azii I Kazahstana, Çast 1., Moskva 1992.

Aukenbayev, Ş T. Ş., Uralo-Embenski Neftenosny Rayon, Alma-Ata 1960.

B. N. Çistov - M. A. Zhohov, Poslanets Partii: Oçerk Voyenno-Politiçeskoy Deyatelnosti P. A.Kobozeva na Vostoçnom Fronte (1918-1919), Moskva: Voyenizdat 1980.

Babich, I. L., Severokavkazkaya Natsia v Evropeiskoi Migratsii: Mif ili Real'nost, SanktPeterburg 2012.

Bademci, Ali, Kendi Arşiv Belgelerine Göre 1917-1934 Türkistan Milli İstiklal Hareketi Basmacılar (Korbaşılar), Kamer Yayınları, 3. Baskı, İstanbul 2019. 
Bashimov, Güçgeldi, "Özbekistan Pamuk Sektörünün Rekabet Gücünün Belirlenmesi”, Türk Tarm ve Doğa Bilimleri Dergisi, 2(1), 2015, s. 99-104.

Boçkaryova, İ. B., - Lisenko, Yu. A. "Natsionalnyy Vopros" i Stanovleniye Sovetskoy Vlasti v Turkestane (1917-1921), Vestnik Tomskogo Gosudarstvennogo Universiteta, No. 429, Tomsk 2018.

Bogdanov, V. N.-Osadçiy, S. P.-Terehov, V. V., Armiya $i$ Vnutrenniye Voyska $v$ Protivopovstançeskoy i Protivopartizanskoy Borbe. Mirovoy Opıt i Sovremennost, Moskova 1997.

Buttino, M., Revolutsiya Naoborot. Srednaya Aziya Mejdu Padeniyem Tsarskoy Imperii $i$ Obrazovaniyem SSSR, Moskva 2007.

Buttino, M., "Ethnicité et politique dans la guerre civile: a propos du Basmačestvo au Fergana", Cahiers du monde russe, T. 38, Frence, 1997, s. 194-223.

Çağlayan, Tuncer, "Büyük Ermenistan Projesi ve İngiltere", Atatürk Araştırma Merkezi Dergisi, G XV/S. 44, Temmuz 1999, s. 513-528.

Çelik, Yüksel, "Ayestefanos ve Berlin Antlaşmalarıyla Ermeni Meselesi’nin Uluslararası Bir Sorun Haline Gelmesi”, https://turksandarmenians.marmara. edu.tr/tr/ayestefanos-ve-berlin-antlasmalariyla-ermeni-meselesinin-uluslararasi-birsorun-haline-gelmesi (Alinma Tarihi: 06.01.2021).

Çugunov, A. İ., Borba na Granitse 1917-1928 (İz İstorii Pograniçnıh Voysk SSSR), Moskva 1980.

Devlet, Nadir, Rusya Türklerinin Milli Mücadele Tarihi (1905-1917), Türk Tarih Kurumu, 3. Baskı, Ankara 2020.

Emrahov, Ziyad, "Rusya Arşiv Belgelerinde Kafkasya’nın Ermeni Din Adamlarının Osmanlı İmparatorluğu'nda Çıkarılmış İsyanlara (1890-1896 Yılları) Verdiği Destek", Ermeni Araştırmalan, S. 49, 2014, s. 115-124.

Farmanov, I., Zapiski o Firme "Nasledniki G.M. Lianozova", Astrahan 1914.

Fursenko, A. A., Neftyanye Trestı i Mirovaya Politika 1880-1918 Gody, Moskva 1965.

Gluşenko, E. A., Rossiyav Sredney Azii. Zavoyevaniya i Preobrazovaniya. Çast 2. Ustroyeniye Kraya, Tsentropoligraf, Moskva 2010.

Grigoryants, A. A., Armyane v Sredney Azii: (Vtoraya Polovina XIX-1917), Erevan: İzdatelstvo AN ArmSSR, 1984. 
Hatunoğlu, Nurettin, "Buhara'daki Ceditçilik Hareketi ve Yaş Buharalılar", SÜTAD, (38), Güz 2015, s. 1-33.

Hayit, Baymirza, (Basmaclar) Türkistan Milli Mücadele Tarihi (1917-1934), Türkiye Diyanet Yayınları, Ankara 1997

İlyutko, F., Basmaçestvo v Lokaye, Moskva 1929.

İrkayev, M., İstoriya Grajdanskoy Voyn v Tadjkistane, Duşanbe: Tadjıkgosizdat 1971.

Kamoliddin, Ş. S., Eşo Raz o Termine Sart. Sogdiyskiy Sbornik. Noveyşiye İssledovaniya po İstorii i Kultury Sogda v Uzbekistane, Saarbrücken 2017, LAP.

Kaufmanskiy Sbornik, Taşkent 1910.

Kerimov, Hatice, Türkistan Genel Valiliği'nde Idari Sistemin Oluşumu ve Gelișim Süreci (1865-1897), T. G. İstanbul Üniversitesi Sosyal Bilimler Enstitüsü Tarih Anabilim Dalı Genel Türk Tarihi Bilim Dalı Doktora Tezi, İstanbul 2019.

Kılınçkaya, Derviş M. - Omarbekov, Talas - Egamberdiyev, Mirzahan, "Sovyetler Birliği Döneminde Yıldırma Politikasının Bir Unsuru Olarak "Türkçülük" Suçlaması", Cumhuriyet Tarihi Araştrrmalar Dergisi CTAD, Yıl 15, S. 30 (Güz 2019), s. 1-27.

Kuropatkin, A. N., Russkaya Armiya, İzdatelstvo Poligon, Sankt-Petersburg, 2003.

Kuts, İ. F., Gody v Sedle, Voyennyye Memuary, Voyenizdat, Moskva 1964.

Kuznetsov, O. Yu., İstoriya Transnatsionalnogo Armyanskogo Terrorizma v XX Stoletii. İstoriko-Kriminalistiçeskoye İssledovaniye, II İzdaniye s Dopolneniyami, Moskva 2015.

Lalayan, A., "Kontrrevolyutsionnı "Daşnaktsutün" i İmperialistiçeskaya Voyna 1914-1918 Godı". Revolyutsşonny Vostok. No. 2-3 (36-37), Moskva 1936, s. 7699.

Litvinov, P. P., Gosudarstvenno-Religioznyye i Etnokonfessionalnyye Otnoşeniya v Turkestane v 1865-1917 Godah. Po Arhivnım Materialam, Dissertatsiya Doktora İstoriçeskih Nauk, Moskva 1997.

Lunin, B. V. - Yusupov, E. Yu, Basmaçestıo - Orudiye Reaktsii (İtoriçeskiye Paralleli), Taşkent 1984.

Maksimoviç, A. A., Basmaçestvo: "Vzglyad Sovetskih İssledovateley. Kazakhstan i Stranı SNG: 20 Let İntegratsii v Globalnıy Kulturno-İstoriçeskiy Kontekst" 
(Sbornik Materialov Mejdunarodnoy Nauçno-Praktiçeskoy Konferentsii, Posvyaşonnıy 20-Letiyu Nezavisimosti Respubliki Kazahstan i 20-Letiyu Obrazovaniya SNG). II. Tom., Almatı 2011.

Maslov, A. I., Zavoyevaniye Ahal-Tepe, Sankt-Peterburg 1887.

Mozohin, O.B., Represii v Tsifrah i Dokumentah. Deyatelnost VÇK-OGPU-NKVDMGB (1918-1953), Moskva 2018.

Mustafayev, Beşir, "Kafkaslarda Müslüman-Türk Soykırımı (1905-1920)", Türk Dünyas Incelemeleri Dergisi, XII/ 1 (Yaz 2012), s. 533-561.

Nazaryan, R. G., Armyane Samarkanda, Moskva 2007.

Nekrasov, V. F., Na Straje Interesov Sovetskogo Gosudarstva: Istoriya Stroitelstva Voysk VÇKOGPU-NKVD-MVD, Voyenizdat, Moskva 1983, s.17-18.

Nialo, Aziz, Oçerki Grajdanskoy Voynı v Kirgizii i Sredney Azii, Frunze 1941.

Niftaliyav, I. V., "Azerbaydjanskaya Diplomatiçeskaya Missiya v Armenii Posle Aprelskoy Okupatsii 1920 g." Istoriya i Yeyo Problemi, No.1, 2006.

Nikişov, P. P., Borba s Basmaçestvom na Nuge Kirgizii, Frunze 1957.

Obzor Zakasriyskoy Oblasti za 1909 God., Aşhabad: Parovaya Tipografiya Gazetı "Aşhabad", 1911.

Omarbekov, Talas, 1929-1931 Fıldarnndağı Hahq Koterilisteri, Zertteu, Arıs, Almatı 2018.

Ordzhonikidze, G. K (Sergo), Izbrannyye Statyi $i$ Reçi. 1918-1937, Moskva: Gospolitizdat, 1945.

Özşavlı, Halil, "Başlangıçtan I. Dünya Savaşına Kadar Rus-Ermeni Iişkileri”, The Journal of Academic Social Science Studies International Fournal of Social Science, Vol. 5/2, April 2012, s. 243-268.

Polyakov, Yu. A. - Çugunov, A. İ., Konets Basmaçestva, Moskva 1976.

Polyakov, Yu. A. - Çugunov, A. İ., Konets Basmaçestva, Nauka, Moskva 1976.

Reforma v Krasnoy Armii. Dokumentr i Materiah 1923-1928, Kniga 2, Moskva 2006.

Rıskulov, Turar, Revolyutsiya i Korennoye Naseleniye Turkestana, Taşkent 1925.

Russkiye Birjevrye Novosti 1914-1915, Petrograd 1915.

Russkiye Birjeryye Novosti, 1915. 
Ruth, Bedevyan, "Ascent to Wealth and Philanthropy of Alexander Mantashev", Armenian News Network 2012.

Ryskulov, Turar, Revolutsiya i Korennoye Naseleniye Turkestana, Taşkent 1925.

Safarov, G. İ. 1924, Osnov Leninizma, Leningrad: Priboy, 1921.

Safarov, G. I., Kolonialnaya Revolyutsiya (Opıt Turkestana), Moskva, 1921.

Salamov, Şuhrat (Barlas Şuhrat), Turkestan i Yujnıy Kafkaz XIX-XX vv. Daşnaki ot Ferganı do Karabaha, Taşkent 2015.

Sbornik Shem $i$ Tablits po Organizatsii $i$ Voorujeniyu Soyedineniy $i$ Voinskih Çastey Krasnoy Armii, Leningrad 1943.

Serbest, Bürkan - Demirci, N. Savaş, "Kars ve Çevresinde Rus Yönetimi (Karskaya Oblast 1878-1917)", 38. ICANAS Uluslararası Asya ve Kuzey Afrika Çalışmalan Kongresi, Ankara 2007.

Soveşenno Sekretno! Tolko Dla Komandovaniya. Dokumentı i Material, Moskva 1987.

Syezdr Sovetov Soyuza SSR, Soyuznı i Avtonomnıh Sovetskih Sotsialistiçeskih Respublik. Sbornik Dokumentov v III Tomah, II Tom, Moskva 1960.

Şarov, A., Zabıty General Kuropatkin, Kommunist Voorujonnıh Sil. No.12, Moskva, 1991. Şaumyan, S. G., , Pisma 1896-1918, Erevan 1952.

Şevçenko, D. F., Formirovaniye Massovogo Basmaçeskogo Dvïjeniya v Sredney Azï Posle Oktyabrskoy Revolyutsii, Irkutsk 2006.

Taşliyev, Ş., Ustanovleniye i Uproçneniye Sovetskoy Vlastiv Turkestane, Aşhabad 1957.

Timofeev, N. - Ahinjanov, M., Kazahskaya SSR, Gospolitizdat 1941.

Togan, Ahmet Zeki Velidi, Bugünkü Türkili (Türkistan) ve Takm Tarihi, Batı ve Kuzey Türkistan, Cilt I, (2. Baskı).

Turkestanskiy Sbornik (Türkistan Koleksiyonu), Kaufmanskiy Sbornik, III. Tom., 1910.

Vambery, Armini, Puteşestviya po Sredney Azï, İzdaniye II. Moskva 1874.

Vnutrenniye Voyska v Godı Mirnogo Sotsialistiçeskogo Stroitelstva 1922-1941. Dokumentı i Materialı, Moskva 1977.

Yazykova M., Borba za Ustanovleniye i Uproçneniye Sovetskoy Vlasti v Zapadnom Turkmenistane, Aşhabad 1957. 
Yelok, Veli Savaş, "Feyzullah Hocayev ve Cedit Hareketi”, Türk Dünyası Bilgeler Zirvesi: Gönül Sultanlarn Buluşması 26-28 Mayıs 2014, Eskişehir 2013, Türk Dünyası Kültür Başkenti Ajansı (TDKB), Eskişehir 2014, s. 423-428.

Yllmaz, Mehmet, - Ferudun Ata, "Buhara Cumhuriyeti Ve Basmacllk Hareketi Hakkında İki Rapor”, Türkiyat Araştrmalan Dergisi, S. 15, (2004), s. 205-225.

Zevelev, A. İ. - Polyakov, Yu. A. - Şişkina, L. B., Basmaçestuo: Pravda İstorii i Vimısel Falsifikatorov, Moskva Misl, 1986. 
